\title{
Repurposing CO2 from Human Respiration Inside Buildings to Enhance Growth in Rooftop Gardens
}

Sarabeth Buckley ( $\square$ sb2481@cam.ac.uk)

University of Cambridge https://orcid.org/0000-0003-0098-1980

Rebecca Sparks

Boston University

Jane Marsching

Massachusetts College of Art and Design

Nathan Phillips

Boston University

Article

Keywords: environmental conditions, green space, carbon dioxide, rooftop gardens

Posted Date: February 17th, 2021

DOI: https://doi.org/10.21203/rs.3.rs-163704/v1

License: (c) (1) This work is licensed under a Creative Commons Attribution 4.0 International License.

Read Full License 
1 Repurposing $\mathrm{CO}_{2}$ from Human Respiration Inside Buildings to Enhance Growth in

2 Rooftop Gardens

3 S. Buckley ${ }^{1}$, R. Sparks', J. Marsching ${ }^{2}$, and N. Phillips ${ }^{1}$

$4 \quad{ }^{1}$ Earth and Environment Department, Boston University, Boston, USA.

$5 \quad{ }^{2}$ Sustainability Studio, Massachusetts College of Art and Design, Boston, USA.

6 Corresponding author: Sarabeth Buckley (sb2481@ cam.ac.uk)

Key Points:

8

- Biologically relevant higher levels of $\mathrm{CO}_{2}$ were found in occupied classrooms and linked to high $\mathrm{CO}_{2}$ from rooftop exhaust vents.

- Growth of crops was increased by 2-4 times with exposure to high $\mathrm{CO}_{2}$ exhaust air from inside buildings.

- Wind speed negatively affected spinach growth and other characteristics of exhaust vent air likely also played a role in enhancing growth.

14 


\section{Abstract}

Cities face many environmental challenges while providing opportunities for integrating human infrastructure with the surrounding environment. One effort to improve environmental conditions in cities is to increase the amount of green space in creative ways within city limits. Here we propose a unique system taking carbon dioxide $\left(\mathrm{CO}_{2}\right)$ from indoor spaces and applying it to rooftop gardens or farms through existing ventilation systems with the elevated $\mathrm{CO}_{2}$ levels leading to a fertilization effect that increases plant growth. $\mathrm{CO}_{2}$ measurements were taken inside multiple classrooms as well as at the exhaust vents on a rooftop and air from exhaust was applied to crops and biomass and leaf number were measured. High concentrations of $\mathrm{CO}_{2}\left(\left[\mathrm{CO}_{2}\right]\right)$ persisted inside university classrooms as well as at rooftop exhaust vents in correlation with expected human occupancy and stayed around $1070 \pm 70$ and 830 parts per million (ppm) $\mathrm{CO}_{2}$ reaching a max of 4470 and $1300 \mathrm{ppm} \mathrm{CO}_{2}$ respectively. Growth in Spinacia oleraceae L. (spinach) grown next to exhaust air increased 4-fold in comparison to plants grown next to a control fan applying atmospheric air. High wind speed decreased growth by approximately 2fold. Zea mays (corn), a C4 plant, grown next to exhaust experienced a 2 to 3 -fold increase, indicating alternative environmental factors additionally playing a part in growth enhancement. Enhancing growth in rooftop gardens using indoor air, could help rooftop plants grow larger and survive harsh conditions. This would make rooftop gardens more viable and better able to provide environmental services and connect urban areas to the surrounding environment.

\section{Introduction}

Cities concentrate people and therefore reduce overall development and destruction of natural ecosystems, at the same time, they change the local environment. Urban areas can be seen as distinct from their surrounding environments because of effects such as the urban heat 
island (UHI) (Memon et al., 2008; Mohajerani et al., 2017; Stathopoulou \& Cartalis, 2007) and altered water cycling patterns (Bounoua et al., 2015; Oberndorfer et al., 2007). Climate change is expected to produce hotter, longer summers with more extreme heat waves (Centers, 2012), which would be exacerbated in hotter cities made of materials that absorb more heat (Elmes et al., 2017; Trlica et al., 2017; Ziter et al., 2019). The presence of More impervious surfaces decreases infiltration and increases run off, erosion, and flooding (Oberndorfer et al., 2007). This excess runoff can contain pollutants and overwhelm current storm water systems (Oberndorfer et al., 2007). Integrating urban areas with the surrounding environment and decreasing differences between urban and non-urban areas could decrease negative impacts of cities on both urban ecosystems and populations.

Expanding green spaces in cities can be one approach to reintegrating urban spaces (Batchelor et al., 2009; Ngan, 2004). Recent studies have found that vegetation in urban areas can have large and unexpected impacts (Briber et al., 2015; Reinmann, 2016; Templer, 2015). While there are fewer trees in cities and therefore a smaller carbon stock, evidence has been found that trees grow significantly faster in cities, though the rate of mortality is high (Briber et al., 2015). Studies of carbon budgets of cities found less, but still considerable amounts of vegetation as well as higher levels of soil carbon in urban versus non-urban areas (Raciti et al., 2012). In a study of Massachusetts and the city of Boston, cities are projected to contain $35 \%$ of the terrestrial carbon sink by 2050 (Reinmann et al., 2016). Changes such as the exportation of detritus from cities also contribute to the unique dynamics observed (Templer et al., 2015). Therefore increasing urban vegetation and ecosystems could influence carbon cycling and overall ecological dynamics within cities. 
Rooftops are greatly underutilized areas occupying approximately 20 to $50 \%$ of urban aerial space (Shafique \& Kim, 2017; US EPA, 2008; Vaughan \& Lenton, 2011). If vegetated, these spaces could provide considerable environmental and social benefits. Rooftop gardens and farms can mitigate the UHI effect by decreasing local temperatures (ArrowStreet, 2016; Ismail et al., 2012; Ito et al., 2015; Kleerekoper et al., 2012; Santamouris, 2014), increasing storm water retention and precipitation release through evapotranspiration, which decreases flooding (Carter \& Rasmussen, 2007; He et al., 2016; Nagase \& Dunnett, 2012; Nitsch, 2016; Shafique et al., 2018; Whittinghill et al., 2015), providing air pollutant filtration (Rowe, 2011), and decreasing building energy use through increased insulation (Garrison et al., 2012; Toudeshki et al., 2013; Wong et al., 2003) and natural cooling (Batchelor et al., 2009; Garrison et al., 2012; Saadatian et al., 2013). Rooftops also offer economic and community building opportunities, aesthetic and mental health benefits (Guite, Clark, \& Ackrill, 2006; Johnson, Malecki, Peppard, \& Beyer, 2018), and food security when used for urban agriculture (Ahmed et al., 2017; Oberndorfer et al., 2007; Orsini et al., 2014). Urban food production would decrease dependency on external communities and increase the redundancy and resiliency of our agricultural system while addressing climate change by helping with climate enhanced negative urban environmental impacts and harvesting $\mathrm{CO}_{2}$ (Davies et al., 2011; Ismail et al., 2012; Oberndorfer et al., 2007; Orsini et al., 2014; Rowe, 2011; Shafique et al., 2020; Whittinghill et al., 2014).

In this paper, we propose a concept for a system that could enhance growth in rooftop gardens and farms. A major challenge facing rooftop gardens is decreased plant growth due to extreme environmental conditions such as higher wind and temperatures, heightened solar radiation, and limited soil moisture content (Ahmed et al., 2017). To help ameliorate these challenges, our system uses air from inside buildings to create more favorable conditions and 
enhance plant growth with $\mathrm{CO}_{2}$ generated from human breath inside buildings. Almost all population growth in the next few decades is expected to occur in cities (Medek et al., 2017; UN, 2017; UN, 2014), with urban populations increasing from 3.65 to 5 billion (Seto et al., 2012).

People stay inside buildings for significant amounts of time and continuously respire large quantities of $\mathrm{CO}_{2}$ which concentrates inside buildings (Apte et al., 2000; Jin et al., 2015; Lee \& Chang, 1999).

This build up of $\mathrm{CO}_{2}$ is most often seen through a public health lens since elevated $\left[\mathrm{CO}_{2}\right]$ can be associated with high levels of other indoor air pollutants (Apte et al., 2000; Lee \& Chang, 1999; Seppanen et al., 1999). The primary direct impact of $\mathrm{CO}_{2}$ on humans is decreased performance and cognitive function (Rice, 2004; Zhang et al., 2018). Concentrations as low as 1000 ppm have been found to significantly decrease performance on mental tasks (Allen et al., 2016; Persily \& de Jonge, 2017; Satish et al., 2012) and concentrations of 2500 ppm have an even larger significant effect (Satish et al., 2012). Therefore legal indoor $\mathrm{CO}_{2}$ limits have been set at 5000 ppm for workspaces with 1000 ppm as a suggested limit (ACGIH, 2011; Apte et al., 2000; EPA, 1991; OSHA, 2012). Some states, such as Massachusetts have even recommended limits of $800 \mathrm{ppm} \mathrm{CO}_{2}$ (MA EOHHS, 2020). However, $\mathrm{CO}_{2}$ regularly is found to exceed these limits inside buildings (Apte et al., 2000b; Lee \& Chang, 1999; Myhrvold et al., 1996; Roulet \& Foradini, 2002).

The $\mathrm{CO}_{2}$ produced in buildings can be harnessed to induce a $\mathrm{CO}_{2}$ fertilization effect on rooftop vegetation. $\mathrm{CO}_{2}$ is typically exhausted from buildings through $\mathrm{HVAC}$ systems and exhaust vents on rooftops. It is possible to apply $\mathrm{CO}_{2}$ in building exhaust to rooftop gardens to increase growth of crops for consumption, yet to our knowledge no study has examined this potential. At elevated concentrations, the $\mathrm{CO}_{2}$ fertilization effect increases photosynthetic 
efficiency (Ainsworth \& Long, 2005) by decreasing photorespiration. Photorespiration is a wasteful side process in plants that occurs in the presence of relatively low $\left[\mathrm{CO}_{2}\right]$ and high concentrations of $\mathrm{O}_{2}$ when the primary enzyme of photosynthesis, Ribulose-1,5-bisphosphate carboxylase/oxygenase (RuBisCO), reacts with $\mathrm{O}_{2}$ instead of $\mathrm{CO}_{2}$. Decreasing photorespiration can increase the amount of carbon taken in by photosynthesis by up to $25 \%$ (Sharkey, 1988).

The effect of the $\mathrm{CO}_{2}$ fertilization effect has been primarily confirmed through Free Air Carbon Dioxide Enrichment (FACE) experiments, which administered higher $\left[\mathrm{CO}_{2}\right]$ to plants within open systems. This allows for the soil-plant-atmosphere continuum to remain intact to garner more realistic assessments (Ainsworth et al., 2008; Kimball et al., 1997; Leakey et al., 2009; Long et al., 2006; McLeod \& Long, 1999; Norby \& Zak, 2011). FACE studies illuminated the potential magnitude of $\mathrm{CO}_{2}$ fertilization on plant growth with limitation from nutrients, photosynthetic strategy, and many other factors (Ainsworth \& Long, 2005; Long et al., 2004; Norby \& Zak, 2011; Nowak et al., 2004). The design of our rooftop garden system is modeled after these experiments, though it differs in that it uses only waste $\mathrm{CO}_{2}$ from human respiration. This provides concentrated $\mathrm{CO}_{2}$ in a more sustainable way and could make this system more feasible and cost effective compared to the $\mathrm{CO}_{2}$ importation of the FACE experiments (Calfapietra et al., 2010; Chakrabarti et al., 2012; Hendrey et al., 1993; Reece et al., 1995). Multiple of the twelve initial FACE experiments are no longer running, potentially in part due to the high cost of purchasing and transporting condensed $\mathrm{CO}_{2}$ (Ainsworth \& Long, 2005; Calfapietra et al., 2010; Chakrabarti et al., 2012; Hendrey et al., 1993; Miglietta et al., 1997; Reece et al., 1995). The proposed system does not apply constant $\mathrm{CO}_{2}$, but is opportunistic and takes advantage of the fact that $\left[\mathrm{CO}_{2}\right]$ is higher during the day in non-residential buildings, which coincides with when plants require $\mathrm{CO}_{2}$ for photosynthesis. Enhancing plant growth would make 
rooftop farms more productive and potentially capable of surviving harsher conditions, expanding their viability as an urban greening strategy.

One study by Sanyé-Mengual et al. (2014) installed an Integrated-Rooftop Greenhouse (iRTG), rather than a garden, on a building in Barcelona, Spain. Indoor air brought to the greenhouse created more hospitable temperatures for growing plants (Nadal et al. 2017), but there was too little $\mathrm{CO}_{2}$ to test for a $\mathrm{CO}_{2}$ induced growth effect. They also did not measure growth in individual plants (Sanjuan-Delmás et al. 2018ab). Greenhouses are expensive both financially and in terms of carbon footprint (van Beveren et al. 2015; Pons et al. 2015; SanjuanDelmás et al. 2018ab; Sanyé-Mengual et al. 2015a; Vadiee and Martin 2013). Shading from the i-RTG decreased output and their hydroponic system did not store extra carbon. Fertilizers used in this system were a considerable amount of the environmental impact. While i-RTGs are a very interesting option, they were not considered in this study for these reasons and because the goal of this study was to develop a system that could be easily implemented on existing rooftops and test for a growth enhancement effect.

We hypothesized that when there is a large build-up of $\mathrm{CO}_{2}$ indoors, enough $\mathrm{CO}_{2}$ is released from exhaust vents to affect plant growth in rooftop gardens, and that plants exposed to exhaust vent air grow larger than plants not exposed to building exhaust. To test this hypothesis, the sources, sinks, and fluxes of $\mathrm{CO}_{2}$ within and out of buildings and atop rooftops were monitored to determine what could be considered the "building metabolism". This $\left[\mathrm{CO}_{2}\right]$ was tracked through the ventilation system and a rooftop garden was built attached to building exhaust vents to test for a $\mathrm{CO}_{2}$ fertilization effect. Applying exhaust air from buildings enhanced plant growth in this rooftop garden. These systems could help make rooftop gardens and farms more robust and therefore a more viable option for building owners and city managers, helping 
152 to use untapped urban resources and make buildings more actively engage with the surrounding 153 environment.

3 Results

$\left[\mathrm{CO}_{2}\right]$ in classrooms varied highly between day and night with spikes in $\left[\mathrm{CO}_{2}\right]$ occurring

158 during scheduled class times. In general, classes ran between 8:00 am and 4:00 pm. During this

159 time $\left[\mathrm{CO}_{2}\right]$ increased dramatically and maintained high concentrations (Figure 2) relative to

160 background $\left[\mathrm{CO}_{2}\right]$. Throughout all classrooms, 37\% of the weekday-time was spent above 1000

$161 \mathrm{ppm}$ with an average daytime concentration of $1060 \mathrm{ppm}$ and maximum of $4470 \mathrm{ppm}$. Levels

162 dropped closer to atmospheric concentration around 410 ppm (Dlugokencky \& Trans, 2018; Ng

163 et al., 2019) by the end of the day. Weekend $\left[\mathrm{CO}_{2}\right]$ were more variable. Based on the subset of

164 classes that were compared with their schedules, increases and decreases in $\left[\mathrm{CO}_{2}\right]$ coincided

165 directly with class times (Figure 2a). As soon as class time started, levels increased though the

166 range of $\left[\mathrm{CO}_{2}\right]$ appeared to vary based on the classroom. This was most likely dependent on both

167 classroom size and the number of students, which were both provided by the 25Live scheduling

168 data. Increased $\left[\mathrm{CO}_{2}\right]$ was almost entirely contained within the times when events or classes

169 were scheduled though there were a few extra peaks as seen in room 213 (Figure $2 b$ ). 
a)

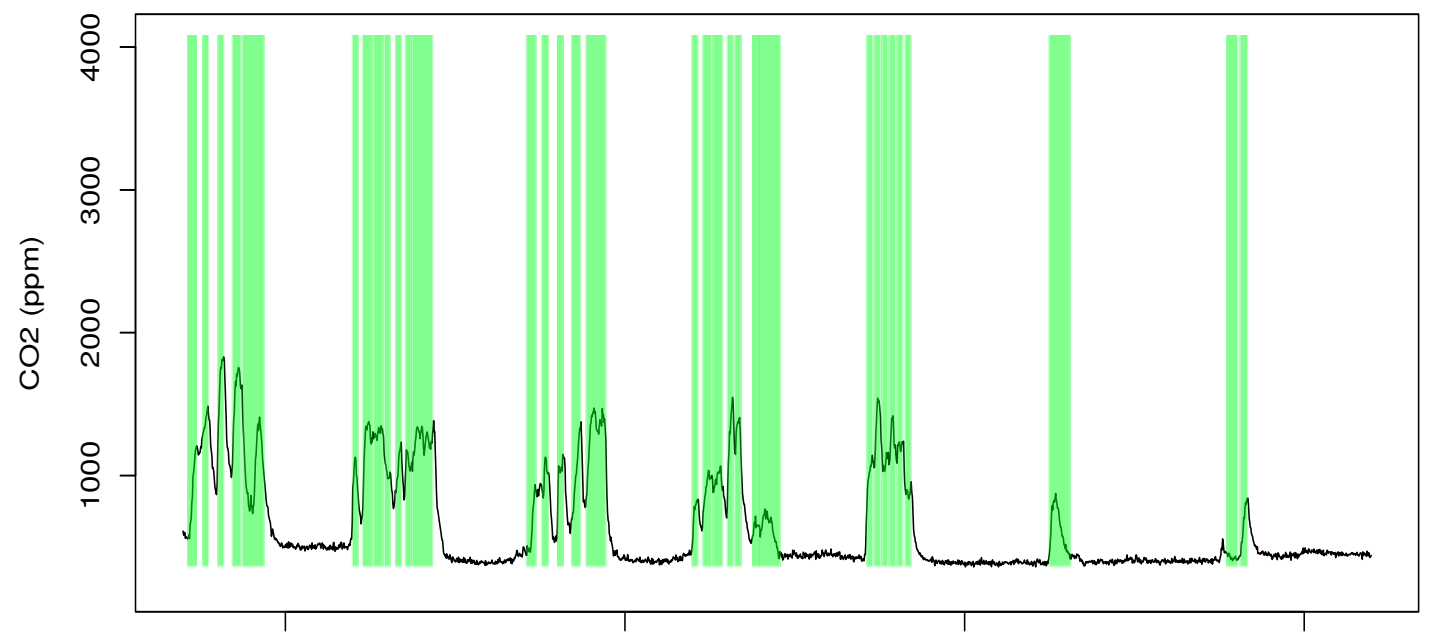

170

b)

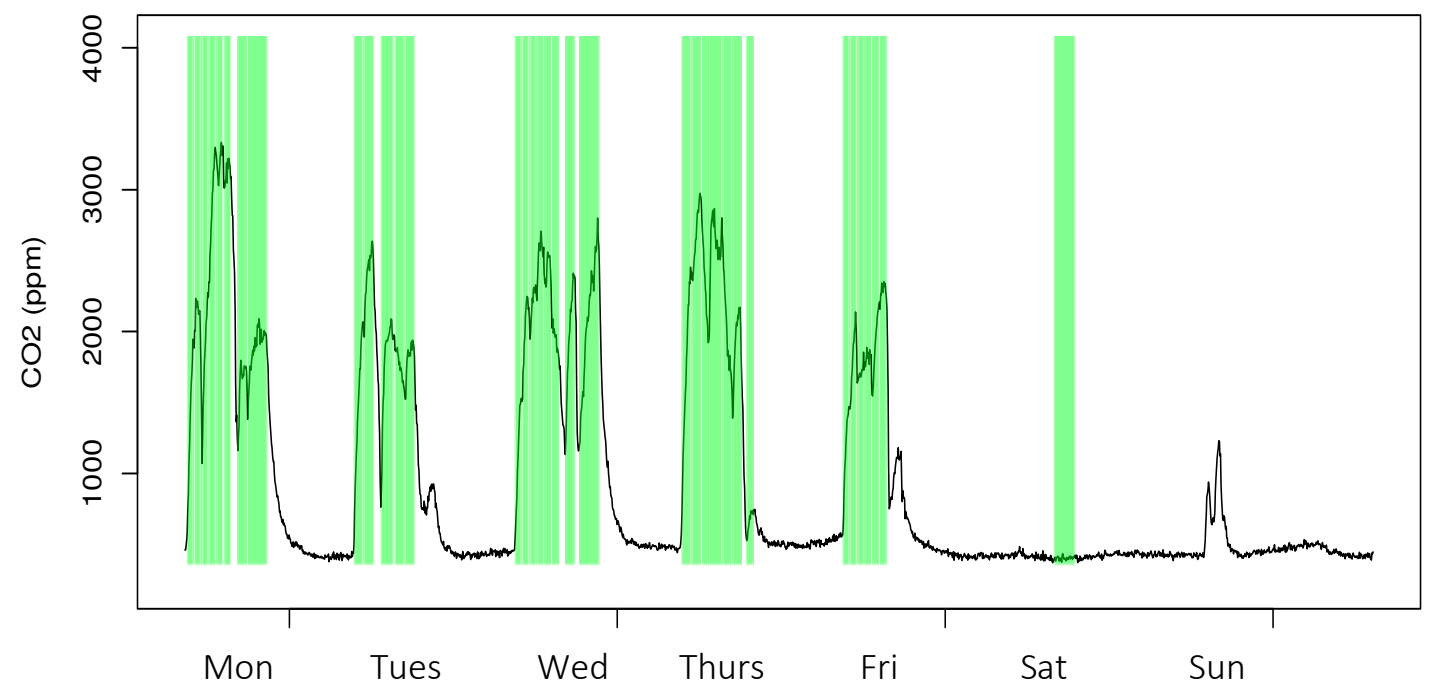

172

Figure 2. Classroom $\mathrm{CO}_{2}$ measurements and class times. $\mathrm{CO}_{2}$ sensors (Onset $\mathrm{HOBO}$ Bluetooth

174 Low Energy Carbon Dioxide - Temp - RH Data Logger, \#MX1102) were installed in

175 classrooms for one week. Occupation data was collected for these classrooms from the 25Live

176 scheduling system used by BU. Class times (green boxes) were plotted against $\mathrm{CO}_{2}$

177 concentrations (black lines) over time to compare $\mathrm{CO}_{2}$ spikes with classroom usage. Spikes occurred primarily during class time in classrooms a) CAS 201 and b) CAS 213. 
Rooftop Exhaust Vent $\left[\mathrm{CO}_{2}\right]$ differed depending on whether summer camp classes were

181 occurring inside the buildings. The measurements taken from the Exhaust Vents over the

182 summer during the first two weeks when very few people were in the building were consistently

183 low and no clear temporal pattern was identified (Figure 3a). Once a camp began during the

184 second two weeks of measurements and the number of people in the building increased to

185 approximately 175 people, a clear pattern became visible. $\left[\mathrm{CO}_{2}\right]$ approached similar levels as

186 seen within the classrooms (Figure 3b) though they were overall lower most likely due to

187 diffusion and leakage in the system. During the weekday-time over the second two weeks of

188 these measurements, Exhaust Vent $\left[\mathrm{CO}_{2}\right]$ stayed above $1000 \mathrm{ppm} 10 \%$ of the time with an

189 average daytime concentration of $830 \mathrm{ppm}$ and maximum of $1300 \mathrm{ppm}$. Similar to indoors,

$190\left[\mathrm{CO}_{2}\right]$ dropped to atmospheric levels around $410 \mathrm{ppm}$ at the end of the day and stayed lower over

191 the weekend. During the rooftop garden experiments, these patterns remained true with daytime

$192\left[\mathrm{CO}_{2}\right]$ from the Exhaust Vents during the week being increased to around the same levels as

193 described above (Figure S1). These correlated well with the indoor $\left[\mathrm{CO}_{2}\right]$ measurements taken in

194 the second floor bathroom (Inside) (Figure S4a). 

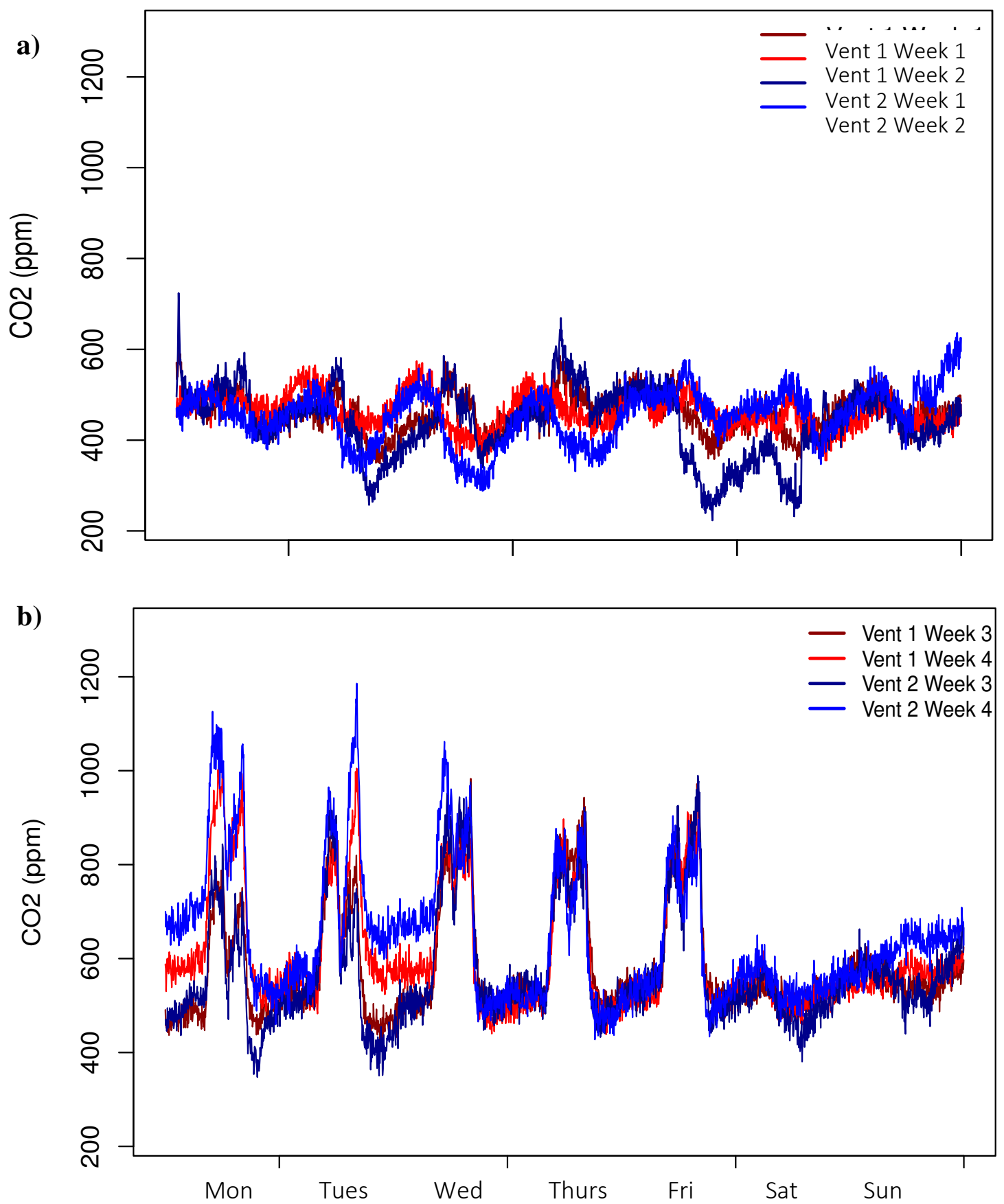

197

Figure 3. $\mathrm{CO}_{2}$ released from rooftop vents on a building while unoccupied and occupied.

199 Sensors were attached to two vents on The BUA roof for four weeks. During the a) first two

200 weeks, only baseline staff were present and the second two weeks a camp was being run. There 
were no $\mathrm{CO}_{2}$ peaks in the first two weeks and peaks up to $1300 \mathrm{ppm}$ during the second two weeks indicating the connection between Exhaust Vent $\mathrm{CO}_{2}$ and building occupancy.

\subsection{Rooftop Garden Experiment}

\subsubsection{Crop Performance, Wind Speed Effect}

In Fall 2018, there was a highly significant difference between growth at the high and low speed fans for both dry $(\mathrm{F}(1,1)=14.96, \mathrm{p}<.001)$ and wet $(\mathrm{F}(1,1)=25.98, \mathrm{p}<.001)$ biomass. The plants grown next to the fans running at the higher speed (17 $\mathrm{mph}$ ) for the Exhaust Vent were significantly smaller than those grown next to the lower speed fan (10 mph) for the Exhaust Vent (Figure 4a; $\mathrm{p}<.001, \mathrm{p}<.001)$. The growth next to both Control Fans was too low for a difference to be detected $(\mathrm{p}=.96, \mathrm{p}=.99)$, but even at the higher wind speed, the growth enhancement effect of the Exhaust Vent significantly increased dry and wet biomass compared to growth next to both the Control Fans at high $(\mathrm{p}=.0058, \mathrm{p}=.011)$ and low speeds $(\mathrm{p}=.0028$, $\mathrm{p}=.043)$.

Even with wind effects, leaf number was higher for plants surrounding the exhaust fan than for plants surrounding the Control Fan (Figure $S 2 b ; F(1,1)=23.64, p<.001$ ). The number of leaves grown next to the Exhaust Vent at the higher speed was less than at the Exhaust Vent at the lower speed $(\mathrm{p}<.001)$, but the difference between leaf number at the high and low speed Control Fans was not significant $(\mathrm{p}=.25)$. The Exhaust Vent effect did still lead to more leaves being produced at the high speed Exhaust Vent in comparison to the high speed Control Fan $(\mathrm{p}=$ .0017). However leaf number at the high speed Exhaust Vent was not significantly different than the leaf number next to the low speed Control Fan $(\mathrm{p}=.23)$. To isolate only the exhaust fan effect, going forward, only the data from the plants surrounding the lower speed fans were used. 
In the Fall 2018, spinach grew larger and had more leaves next to Exhaust Vents. The dry

225

226

227

228

229

230

231

232

weight $($ Figure $4 b ; F(1,1)=56.87, p<.001)$, wet weight (Figure $S 7 b ; F(1,1)=57.69, p<.001)$, and leaf number (Figure $\mathrm{S} 2 \mathrm{~b} ; \mathrm{F}(1,1)=41.11, \mathrm{p}<.001$ ) of the spinach next to Exhaust Vents were significantly greater than those of the spinach grown next to the Control Fan. The average dry weight of plants next to the Exhaust Vent was $0.45 \mathrm{~g} \pm 0.013( \pm \mathrm{SE})$ compared to $0.12 \pm$ 0.041 at the Control Fan. The average leaf number of plants next to the Exhaust Vent was $7 \pm$ 0.08 compared to $5 \pm 0.15$ at the Control Fan. Dry biomass around the Exhaust Fan was almost four times larger than dry biomass around the Control Fan with means of $0.45 \pm 0.04 \mathrm{~g}$ and 0.12 $\pm 0.13 \mathrm{~g}$.

During Spring 2019, there was a significant difference in the corn dry and wet biomass $(\mathrm{F}(1,2)=10.13, \mathrm{p}<.001, \mathrm{p}<.001)$ with the growth next to the Exhaust Vent being significantly higher than at both the Control Fan and the Control for both dry $(p<.001, p=.0045)$ and wet (Figure S7; $<<.001, \mathrm{p}=.012$ ) biomass. There was also a difference in color between the treatments (Figure S3) with corn next to exhaust vents appearing greener than corn next to the control fans which appeared more yellow. The corn was between 2 and 3 times larger at the Exhaust Fan versus the Control Fan with means of $0.17 \pm 0.005 \mathrm{~g}$ and $0.065 \pm 0.008 \mathrm{~g}$. 

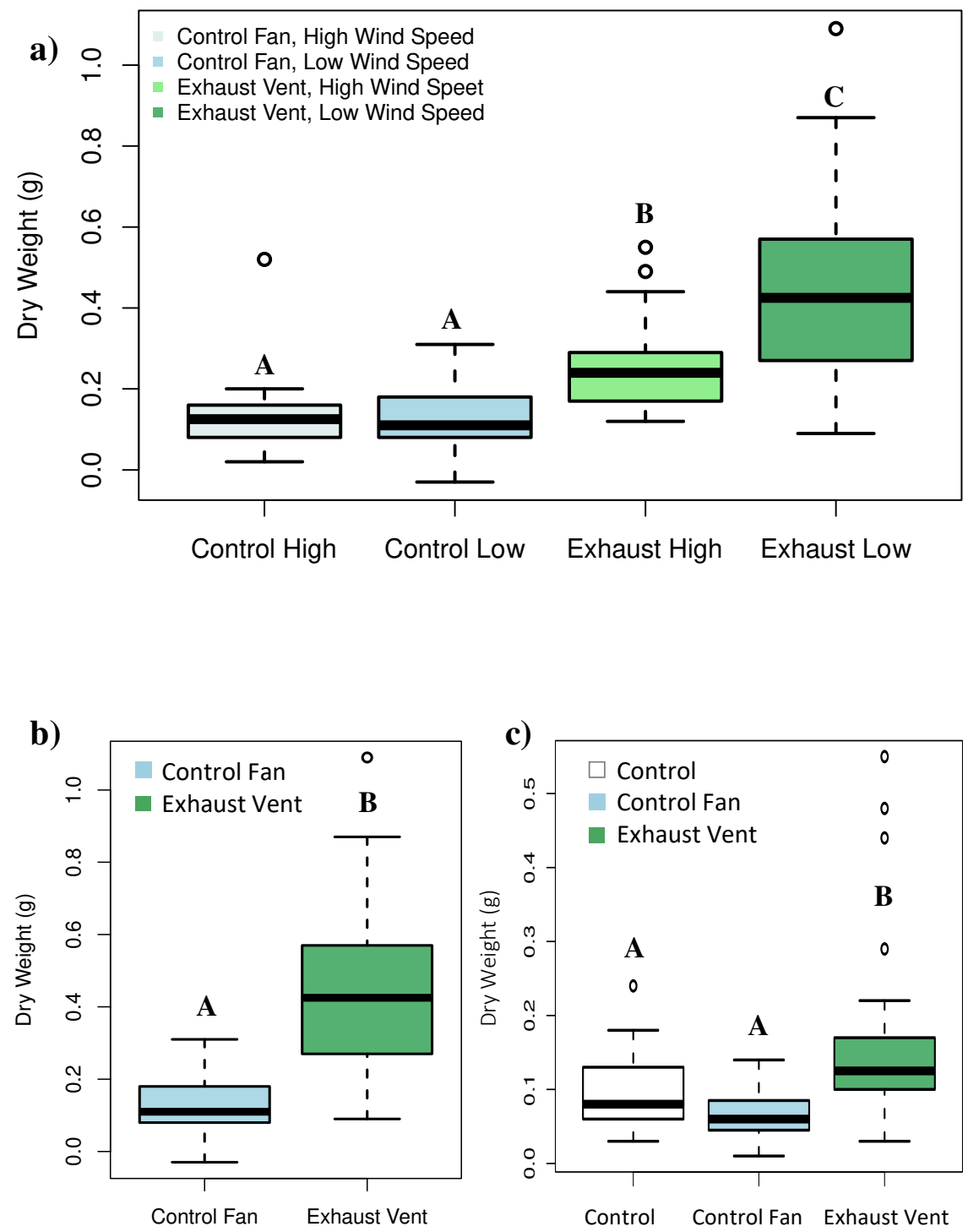

Figure 4. Average dry weight of spinach and corn plants in response to Exhaust Vent air. a)

244 Spinach was grown in Fall 2018 next to two fans at a higher wind speed (17 mph) and two at a

245 lower speed (10 mph) and one of each of these was a Control Fan and Exhaust Vent. Between

246 the Exhaust Vents, the spinach plants exposed to high wind speeds were smaller $(\mathrm{p}<.001)$. Even

247 with this, the Exhaust Vent was able to recover growth compared to both the low $(\mathrm{p}=.0058)$ and

248 high-speed $(\mathrm{p}=.0028)$ Control Fans. At only low wind speeds there was a significant increase in

249 b) dry biomass $(\mathrm{p}<.001)$ with exposure to exhaust air. These data were from harvest 3. c) Corn 
250 was grown in Spring 2019 to look at the response of a crop that should not respond strongly to

$251 \mathrm{CO}_{2}$. Another control was added to further assess the effect of wind speed. Corn grown next to

252 the Exhaust Vent was larger than at both the Control Fan $(\mathrm{p}<.001)$ and control garden $(\mathrm{p}=$

253 0.0045). Different capital letters indicate statistically significant differences among treatments.

254

\subsection{Environmental Measurements}

For soil moisture, no significant differences were found (Figure S2a). Data from the last day of data collection was used for consistency with harvest and leaf number measurements. Frost covering the rooftop in November showed an approximately $2 \mathrm{~m}$ outline around the exhaust vents where the warmer indoor air melted the frost (Figure S11a) in contrast to around the control vents (Figure S11b) where no outline was seen giving a preliminary indication of the spatial extent of the effect.

\section{Discussion}

\subsection{Building Metabolism}

"Building Metabolism" could be considered to be all of the sources, sinks, and fluxes of $\mathrm{CO}_{2}$ in a building (Sanyé-Mengual et al. 2014; Pons et al. 2015). Ventilation brings in fresh air based on indoor temperatures and energy efficiency while used indoor air is either recycled back into the room or exhausted from vents, releasing $\mathrm{CO}_{2}$ into the atmosphere. $\mathrm{CO}_{2}$ could be diluted by diffusion or lost through windows, doors, and leaks and introduce differences between concentrations in indoor spaces and the exhaust stream.

Humans were the most important source of $\mathrm{CO}_{2}$ in this study leading to high levels both indoors and in exhaust vent air. Normally indoor $\left[\mathrm{CO}_{2}\right]$ measurements are used in the context of health and energy efficiency. This study also considers $\left[\mathrm{CO}_{2}\right]$ in classrooms from the perspective 
272 of using $\mathrm{CO}_{2}$ as a resource for plant growth. As expected, considerable build-up of $\mathrm{CO}_{2}$ was

273 found during the daytime from human respiration connected with scheduling patterns (Figure 2).

274 A more surprising result is how high $\left[\mathrm{CO}_{2}\right]$ persists and for how long it remains high. Daytime

$275\left[\mathrm{CO}_{2}\right]$ from Monday to Friday remained above suggested limits of $1000 \mathrm{ppm}$ over a third of the

276 time people were in the classrooms (Figure 2). This could be problematic for students and other

277 BU community members whose performance could be affected by the $\left[\mathrm{CO}_{2}\right]$ since even

278 concentrations of $1000 \mathrm{ppm}$ have been found to be detrimental to mental performance (Allen et

279 al., 2016; MA EOHHS, 2020; Persily \& de Jonge 2017; Satish et al. 2012). It would be

280 beneficial to reassess the current system and make necessary changes to decrease $\left[\mathrm{CO}_{2}\right]$. In

281 exhaust vents, $\left[\mathrm{CO}_{2}\right]$ was slightly lower than, but still fairly similar to, indoor air levels (Figure

$282 \mathrm{~S} 4$, Figure S6). The clear change in pattern in the $\left[\mathrm{CO}_{2}\right]$ exhaust vent data when there were and

283 were not people in the building (Figure 3) supports the hypothesis that human respiration also

284 drives $\mathrm{CO}_{2}$ fluxes from exhaust vents, which are therefore still representative of and influenced

285 by overall building metabolism.

\subsection{Plant Growth Enhancement}

The overall $\left[\mathrm{CO}_{2}\right]$ patterns found for exhaust air (Figure 3) indicate that it could be used

to induce $\mathrm{CO}_{2}$ fertilization and act as a resource for plant growth enhancement. Exhaust air

$289\left[\mathrm{CO}_{2}\right]$ was between 500 and $1000 \mathrm{ppm}$. As $\left[\mathrm{CO}_{2}\right]$ increases above $400 \mathrm{ppm}$, photosynthesis

290 increases until approaching around 1000 ppm (Rogers et al. 1994) when you begin to see

291 diminishing returns. Plant physiology can also be altered by higher $\left[\mathrm{CO}_{2}\right]$. A study by Fleisher et

292 al. 2008 looked at interactive effects of drought and higher $\left[\mathrm{CO}_{2}\right]$ and found that characteristics

293 such as stem and apical stem length, plant length, leaf appearance duration and rate, leaf area,

294 and leaf number can be altered by higher $\left[\mathrm{CO}_{2}\right]$ though primarily through interactive effects. The 
fact that these characteristics could vary based on $\left[\mathrm{CO}_{2}\right]$ could help explain the increase in leaf number found in this study (Figure S2b) and be part of the mechanism for increased biomass in plants exposed to exhaust vent air (Figure 2b).

Intermittent application of increased $\left[\mathrm{CO}_{2}\right]$ could alter the effectiveness of the $\mathrm{CO}_{2}$ fertilization effect. This system involves inherent variability in $\mathrm{CO}_{2}$ application since $\mathrm{CO}_{2}$ is not constantly produced or applied. Some studies found that when $\mathrm{CO}_{2}$ is applied intermittently, as in for some number of hours or days on and off, this can decrease the $\mathrm{CO}_{2}$ fertilization response though significant increases were always found (Clough and Peet, 1981; Mortensen, 1986; Both et al., 1998 Both 2002). While the weekends would most often be days without $\mathrm{CO}_{2}$ application, this system would still apply $\mathrm{CO}_{2}$ constantly throughout most days. A study by Calvert and Slack (1976) showed that as long as you apply $\mathrm{CO}_{2}$ through most of the day, you still get a similar increase and it's more important to apply $\mathrm{CO}_{2}$ in the morning than later at night, which would be the case in this system. Some FACE studies purposely created a system where $\mathrm{CO}_{2}$ was applied intermittently, only during the day either to match the timing of photosynthesis or because $\left[\mathrm{CO}_{2}\right]$ was already higher at night. Growth enhancement effects were still found in all studies (Miglietta et al., 1997; Moore et al., 1999; Edwards et al., 2001; Leakey et al., 2009).

This application system is also opportunistic since it redirects air already being expelled through exhaust vents towards plants. It avoids complicated and energy intensive processes such as condensing the $\mathrm{CO}_{2}$ or controlling application to produce a constant $\mathrm{CO}_{2}$ source, which would alter the overall carbon footprint of this system. This makes this system easier to construct, which would aid in wider implementation.

It is both plausible and probable that factors aside from $\left[\mathrm{CO}_{2}\right]$ affect plant growth. Potential examples include temperature, relatively humidity, and wind speed. This study 
hypothesized that $\left[\mathrm{CO}_{2}\right]$ would impact growth while attempting to get a preliminary understanding of whether other factors contribute as well by growing both a $\mathrm{C} 3$ and a $\mathrm{C} 4$ plant, spinach and corn (Figure 4). C3 plants should have a stronger response than C4 plants to increased [CO 2 (Ainsworth \& Rogers, 2007; Hatfield et al., 2011; Kimball et al., 2002; Long et al., 2006; Nowak et al., 2004; Sharkey, 1988). This is because C4 metabolism is a photosynthetic process specifically designed to increase $\mathrm{CO}_{2}$ uptake efficiency, so even at low concentrations it already experiences higher concentrations and rates of photosynthesis, which therefore would not be changed by higher external levels (Ainsworth \& Rogers, 2007). However, in this study, there was a multiple-fold increase in growth for both spinach in the fall and corn in the spring (Figure 4), implying other environmental factors such as temperature could be enhancing plant growth. Both spinach and corn are sensitive to temperature and have approximate optimal temperatures of $20{ }^{\circ} \mathrm{C}$ for spinach and $30{ }^{\circ} \mathrm{C}$ for corn (Warrington \& Kanemasu, 1983; Boese \& Huner, 1990; Yamori et al., 2006), so the buffering effect of applying heated internal air would theoretically assist in avoiding extreme temperatures.

Studies have looked at the different and combined effects of $\left[\mathrm{CO}_{2}\right]$ and temperature on plant growth in multiple species (Nijs et al., 1997; Zvereva \& Kozlov, 2006; Cai et al., 2016) including corn (Hatfield et al., 2011; Tongson et al., 2017). $\left[\mathrm{CO}_{2}\right]$ and temperature are two of the most critical factors relating to plant growth and are highly likely to be altered by climate change (Dentener et al., 2013). This initial observational study indicates that future studies able to fully control for $\left[\mathrm{CO}_{2}\right]$, temperature, and other environmental factors should be considered.

\subsection{Environmental Impact and Scaling Up: Preliminary Calculation of Potential Impact}

This exhaust air application system could improve an overall carbon footprint in multiple ways. In relation to carbon harvesting systems, it would be more sustainable for using 
341 concentrated waste $\mathrm{CO}_{2}$ from human respiration instead of from fossil fuel exhaust as do almost

342 all current large-scale carbon removal attempts. The system's associated rooftop garden or

343 farm's more direct carbon footprint would include the carbon stored in the garden, the embodied

344 carbon or carbon emitted in building the garden, and avoided carbon emissions from

environmental benefits. Whittinghill et al. 2014 found that stored carbon varied based on species with herbaceous plants and grasses holding an average of $68.2 \mathrm{~kg} \mathrm{C} \mathrm{m}^{-2}$ compared to $0.38 \mathrm{~kg} \mathrm{C}$ $\mathrm{m}^{-2}$ in sedum gardens (Getter et al., 2009). Getter et al. 2009 estimated embodied carbon to be $6.5 \mathrm{~kg} \mathrm{C} \mathrm{m}^{2}$. Avoided $\mathrm{CO}_{2}$ emissions could be expected from either decreased energy use of the building below (Batchelor et al., 2009; Garrison et al., 2012; Oberndorfer et al., 2007; Toudeshki et al., 2013) primarily from 10 to $43 \%$ decreases in air conditioning use (Meier, 1990; Garrison et al., 2012), or avoided transport of food from rooftop farms (Pirog et al., 2001; Halwell, 2002; Weber and Matthews 2009; Lower \& Dining, 2014). Pirog et al. 2001 found produce brought to Chicago travels an average of 1,518 miles and that using local food from the surrounding area reduced the associated carbon emissions by 5 to 17 times. Studies from the i-RTG project, which contains more carbon costs associated with infrastructure, found the environmental impact of their produce would be lower from decreased packaging and transportation (Sanye-Mengual 2015ab).

For our preliminary calculations of impact, since vegetables would be one of the primary commodities and benefits rooftop farms could provide to urban communities, we attempted to quantify potential increases in yield from this system. Orsini et al., 2014, looked at vegetable production in rooftop farms in a field study conducted to optimize the amount of crops that could be produced. They used their estimate to scale up across the city of Bologna, Italy by identifying all of the flat rooftops and determining that $77 \%$ of produce used by the city could be grown in 
rooftop farms within city limits. We extended this to estimate how many more vegetables they could produce using a system such as the one described here. Given the limitations of this study, we assumed similar increases in yield could be found for different crops across the growing season in different environmental conditions, which would increase the productivity of an individual rooftop area. We found that $86 \%$ to $144 \%$ of required vegetables could be produced depending on the spatial extent of the effect and number of vents on buildings (Table S1). This was also expanded to Boston where, using only growth rates from Orsini et al., an estimated $190 \%$ of required vegetables could be produced. By adding exhaust vent application systems, $207 \%$ to $290 \%$ of Boston's vegetable requirement could be produced (Text S1, Table S1). This indicated that covering rooftops within a city with rooftop farms could contribute a substantial amount of produce to the overall needs of the city.

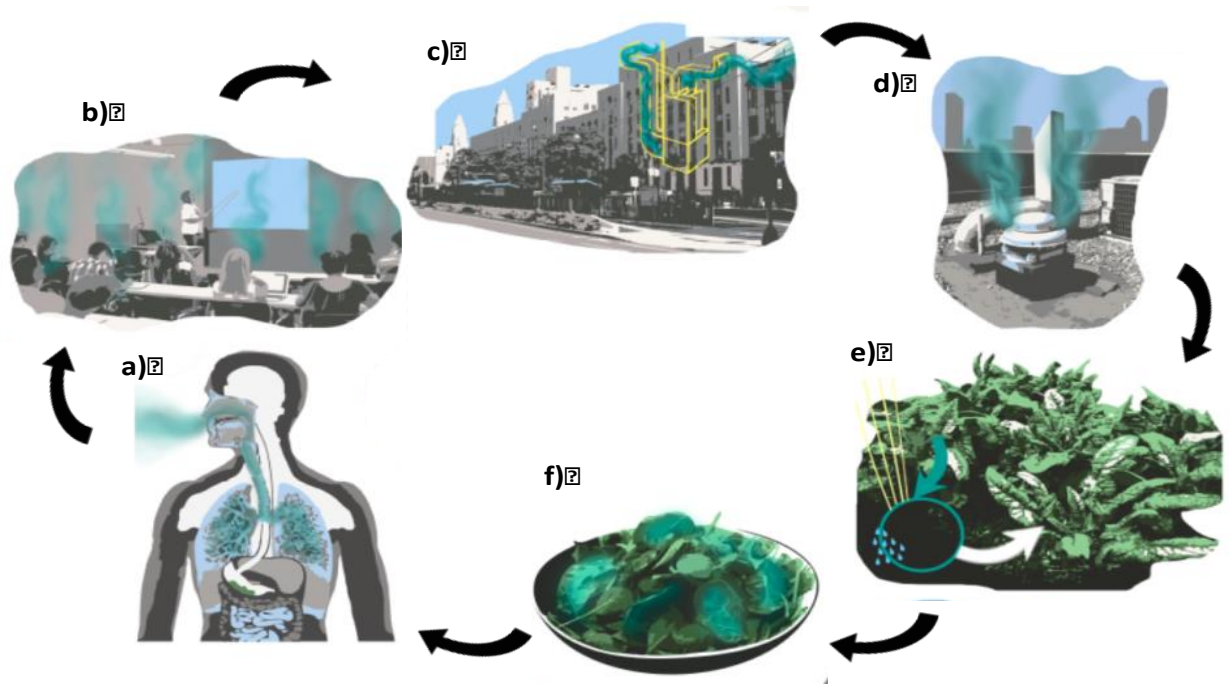

Figure 5. Conceptual diagram showing the carbon cycle within experimental rooftop gardens. $\mathrm{CO}_{2}$ travels a) from the human body b) out into the classroom within a building. This $\mathrm{CO}_{2}$ then is brought c) through the ventilation system to the rooftop and d) released through an exhaust vent. Our system will apply this $\mathrm{CO}_{2}$ to e) plants in a rooftop garden after which f) humans can consume the crops and the carbon can return to the human body. 


\section{4 $\mathrm{CO}_{2}$ Application System Design and Implementation Considerations}

The system described in this study creates a more circular carbon process with high $\left[\mathrm{CO}_{2}\right]$ from human respiration (Barrett et al., 2012) traveling through the building, into the garden system where some is used (Hanson et al., 2000) to produce food that can be eaten by humans and respired anew (Figure 5). While a fascinating concept, there are many opportunities for optimizations. Ideal wind speed must be identified since higher wind speeds negatively impacted plant growth (Figure 4a). Air from the fans could either dry out the soil or physically impact the plant (Onoda \& Anten, 2011). Rooftop gardens can be relatively dry given the hotter temperatures experienced on rooftops, impacting soil moisture (Ahmed et al. 2017). Weight restrictions on buildings also limit soil depth and therefore how much water can be stored. Throughout the year, temperature, relative humidity, etc. can be higher or lower in exhaust vent air compared to outdoor air depending on how we are modifying our internal environment.

\section{During the Fall, internal and therefore exhaust vent air had a lower relative humidity than} outdoor air. However, there were no differences found in soil moisture between treatments or by wind speed (Figure S2). Therefore this was most likely not the mechanism of growth inhibition. The mechanical impact of the air and/or its desiccating tendency on leaves could have caused the decrease in growth. Some wind is necessary for plants to develop their overall structure (Onoda \& Anten, 2011), but they are limited by higher wind speeds (Bang et al., 2010). A unique vent or vent attachment could be designed that decreases wind speed at the plant, while maintaining conditions that increase growth. The air could be funneled into a series of tubes that run along the soil and release exhaust vent air upward or sideways towards the plants. This could be addressed with mechanical engineering approaches and further knowledge of gas and fluid transport. 
New designs should also increase the spatial extent of the exhaust effect. Opportunistic

405

406

407

408

409

410

411

412

413

414

415 frost observations gave a preliminary indication of the current extent (Figure S11ab), but sensors could be placed at different distances from the vent to measure where conditions return to background. Plants could be grown in lines extending away from the vent to determine the extent of the growth effect, which is the desired impact. Designs could also be developed that entirely replaces normal ventilation fans but should at least account for different types and numbers of exhaust vents, which could be identified by a survey of many buildings. As previously mentioned, a full factorial experiment that controls for the different variables, especially $\mathrm{CO}_{2}$ and temperature, should be carried out since this was an observational study mostly limited to looking at overall effects of ventilation air on plants as a proof of concept experiment. Isotopes could be used to determine how much of the $\mathrm{CO}_{2}$ in these plants was from human breath versus atmospheric air to confirm or disprove the influence of $\mathrm{a} \mathrm{CO}_{2}$ fertilization effect.

Further development of this system could be used as an inexpensive method for conducting more FACE studies that use a waste source of $\mathrm{CO}_{2}$ and therefore would not be inhibited by high $\mathrm{CO}_{2}$ costs. This could provide options for studies on gradually increasing [CO 2$]$ (Miglietta et al., 1997), different kinds of plants, how to optimize production (Ainsworth et al., 2008; Ainsworth \& Long, 2005), how responses might change with different combinations of factors (Cai et al., 2016; Nijs et al., 1997), and whether or not the $\mathrm{CO}_{2}$ fertilization effect decreases the nutritional content of crops (Idso \& Idso, 2001; Loladze, 2002; Myers et al., 2014; Medek et al., 2017). The response of plant nutrients and secondary chemicals grown in this system might be different than in other FACE studies since there are differences in nutrient cycling in cities when compared to rural, natural and other agricultural sites (Rao et al., 2014; Templer et al., 2015; Decina et al., 2016) with higher [ $\left.\mathrm{CO}_{2}\right]$, temperature, ozone, nitrogen, and 
other environmental factors (Briber et al., 2015; Patterson \& Eatough, 2000; Weschler, 2006; Xue et al., 2014) which could change plant responses (Kangasjärvi et al., 2005; Prajapati, 2012; Rao et al., 2014). The effects of increased $\left[\mathrm{CO}_{2}\right]$ in urban systems in general as well as different biomes could be examined. While this study focuses on urban environments, it is important to note that this concept could also be applied to buildings in rural areas if a large enough number of people are present in a building.

The influence of this system could be understood for different plants and for buildings with different building metabolisms as well as for what plants would be best suited for each building type. For example, there could be building types where people are more likely to inhabit the building at night, which would decouple the largest source of $\mathrm{CO}_{2}$ from the time when the plants are growing most. This type of building might benefit from a storage and concentration option or growing plants using a CAM photosynthetic strategy. In a school building, the largest number of people will be inside from September until May or June, so cold weather crops like spinach and kale could be easier to produce. An office building would most likely be occupied throughout the year and a wider variety of crops could be grown for a longer period of time. Therefore different design considerations would most likely have to be made for different types of buildings.

\section{Conclusions}

Cities are facing a variety of environmental challenges and it would be beneficial to find ways to grow plants on underutilized rooftops. To our knowledge, this is the first study to take indoor air with higher $\left[\mathrm{CO}_{2}\right]$ and apply it to plants grown in a rooftop garden or farm. The enhanced growth found is consistent with a $\mathrm{CO}_{2}$ fertilization effect as characterized by FACE experiments though it also indicates the influence of other environmental characteristics of the 
exhaust vent air, such as temperature, in increasing growth. There is a lot of potential for further optimization of the system design, but this system takes advantage of an underutilized resource that particularly exists in large quantities in cities and opens the door for considering other potential unique resources such as nutrients, microclimates, etc. Depending on further assessments of scaling up this system, implementing this approach on rooftops across cities and increasing overall urban vegetation could help address some environmental challenges facing cities including producing hyper local food more efficiently and sustainably, harvesting carbon, and helping integrate into the surrounding environment.

\section{Materials and Methods}

Experiments were carried out in the fall of 2018 and the spring of 2019 in the northeastern United States in Boston, Massachusetts. $\left[\mathrm{CO}_{2}\right]$ and other environmental measurements were taken inside of classrooms and at the rooftop exhaust vents. The vent air was directed at the plants, spinach and corn, and the effect on growth was measured.

\subsection{Site Selection}

Buildings and rooftops at Boston University (BU) were used for this research. The local facilities staff was consulted in order to determine the safest location for the experiment, with considerations including condition of the roof, accessibility, and presence of parapets around the edge of the roof. Eight buildings were identified and an initial survey of exhaust $\left[\mathrm{CO}_{2}\right]$ was conducted. Short-term measurements of $\left[\mathrm{CO}_{2}\right]$ were taken during the middle of the day when buildings were occupied. Initial results indicated that $\left[\mathrm{CO}_{2}\right]$ was elevated at most buildings, ranging from $500 \mathrm{ppm}$ to $1000 \mathrm{ppm}$ in comparison to atmospheric $\mathrm{CO}_{2}$ at $410 \mathrm{ppm}$. A high school on the BU campus, the BU Academy (BUA), located at 785 Commonwealth Avenue had 
$472 \mathrm{CO}_{2}$ levels of approximately $700 \mathrm{ppm}$ and was chosen as the site for the rooftop garden/farm 473 experiments. A large academic building, The College of Arts and Sciences (CAS), 725

474 Commonwealth Avenue, was also chosen for further indoor $\left[\mathrm{CO}_{2}\right]$ measurements due to its

475 central location on campus and the use of an online scheduling system within the building that provided more information about building occupation.

2.2 $\mathrm{CO}_{2}$ and Classroom Measurements

\subsubsection{Classroom Occupancy Data}

25Live (CollegeNET, Portland OR) is a scheduling software used at multiple universities, including BU. It assists with classroom management in buildings like CAS. This system allows for approved community members to reserve spaces for various events including classes. Event room, date, time, and anticipated occupancy data along with room size were collected from this system for 20 classrooms for the weeks during which the $\left[\mathrm{CO}_{2}\right]$ sensors were installed.

\subsubsection{Indoor Classroom $\left[\mathrm{CO}_{2}\right]$ Measurements}

From January 2018 through March 2019, three [CO 2$]$ monitors (Onset HOBO Bluetooth Low Energy Carbon Dioxide - Temp - RH Data Logger, \#MX1102) were installed in 20 classrooms throughout CAS. There was an initial factory calibration process where the monitors were placed outside and calibrated for 5 minutes using this internal system when first acquired and before use. Additionally, monitors were cross-checked with each other across a range of $\left[\mathrm{CO}_{2}\right]$ by placing them together in a closed chamber with a series of $\left[\mathrm{CO}_{2}\right]$ produced by human breath. Overall measurements as well as trends matched across all three monitors. Factory calibrations were also compared with and found to be within $\pm 50 \mathrm{ppm}$ of a $400 \mathrm{ppm}$ standard compressed air source (AirGas, Rendon, PA), which is close to the current atmospheric 
494 background $\left[\mathrm{CO}_{2}\right]$ of $410 \mathrm{ppm}$ at the time of the study (Dlugokencky \& Trans, 2018; $\mathrm{Ng}$ et al., 495 2019).

Sensors were placed within classrooms at approximately the same height $(1.5 \mathrm{~m}$ above

497 the ground) and location as permanently installed $\left[\mathrm{CO}_{2}\right]$ sensors and air monitors found within

498

499

500

501

502

503

504

505

506

507

the classrooms. Installment of these sensors allowed us to make measurements reflective of those taken by the university. The approximate height was between 1.25 and $1.5 \mathrm{~m}$, which is also similar to other studies (Lee \& Chang, 1999). Logging was started at least 2 minutes after installation to prevent $\mathrm{CO}_{2}$ contamination from the breath of the investigators. No installation effect was ever identified. A week was used as the time frame for each classroom to capture the dynamics throughout a normal workweek and over the weekend when different usage patterns were expected. Classrooms were primarily used because they represent a primary function of the school building. It is a relatively confined space occupied by multiple people for a designated period of time and therefore easier to track.

\subsubsection{Rooftop $\mathrm{CO}_{2}$ Measurements}

The $\left[\mathrm{CO}_{2}\right]$ sensors were also installed on vents on top of the BUA roof. Two sensors were placed on Direct Drive Centrifugal Roof Exhausters Model PRN (ACME Engineering and Manufacturing Corporation, Muskogee, OK) and two were placed on control fans of the same type installed at separate locations on the BUA rooftop. We chose these vents, commonly referred to as mushroom vents, because of their prevalence on rooftops and the higher than normal $\left[\mathrm{CO}_{2}\right]$ found in their exhaust air in comparison with other vents. Through discussions with facilities and inspection of building plans, they were also identified as general exhaust from internal human-occupied spaces. The sensors measured the $\left[\mathrm{CO}_{2}\right]$, temperature and relative humidity of emitted exhaust vent air to determine whether $\left[\mathrm{CO}_{2}\right]$ is higher than the atmospheric 
517 concentration and if measurements are correlated to internal dynamics connected to human usage 518 of the building.

Sensors were first installed at the exhaust vents for four weeks from June $25^{\text {th }}$ to July $22^{\text {nd }}$ of 2018 to understand dynamics during periods of time when there were varying amounts of

521 people in the building. Information regarding the schedule of the building was obtained. During 522 the first two weeks, only instructional staff (no students) were present during the day, which 523 consisted of 10-15 people. During the second two weeks, a camp program was run with around 524175 students attending classes regularly throughout the day.

The rooftop sensors were also run throughout the rooftop garden experiments. During this time, a sensor was installed within a bathroom on the second floor of the BUA. Blueprints

527 for the design of the building indicated that this location was most likely the closest point within 528 the building to where the exhaust vents were connected. This could be because the vents 529 associated with restrooms fall under specific guidelines and are always operational and 530 constantly remove air from inside the building. These could be less directly connected to 531 classroom $\left[\mathrm{CO}_{2}\right]$, but given general circulation and diffusion, could be representative of overall $532\left[\mathrm{CO}_{2}\right]$ within a building.

\subsubsection{Plant Growth: Study Species}

Spinach (Spinacia oleraceae L.), used for the majority of rooftop garden experiments, is an economically and nutritionally important crop (Min, 2014; Reddy et al., 2014). It has a high nutritional value (Kuti \& Konuru, 2004) and notable quantities of secondary chemicals (Nuutila, 2002; Bunea et al., 2008; Shohag et al., 2011), which protect against chronic diseases (Howard et 
al., 2005). It is a cold-season crop from southwestern Asia (Candlish et al., 1987), important because all experiments were run in the fall and spring seasons. This timing was used because this is when the largest number of people are present in university and high school buildings and the study was testing the impact of exhaust vent air with potentially higher $\left[\mathrm{CO}_{2}\right]$ from those people on plant growth. Spinach also utilizes the C3 photosynthetic metabolic pathway, which is more responsive to elevated $\left[\mathrm{CO}_{2}\right]$ over the expected range studied here than plant species with other metabolic pathways (Kimball et al., 2002; Nowak et al., 2004).

Corn (Zea mays) was grown in the spring to explore the effect of other characteristics of the exhaust vent air such as temperature. Corn is originally from Central America and the most widely planted crop in the United States with 31.9 million ha planted in 2002 (Kadam \& McMillan, 2003). It has less tolerance for cold than spinach (Warrington \& Kanemasu, 1982), but is known to use a $\mathrm{C} 4$ carbon fixation strategy, which makes it less sensitive to increased $\left[\mathrm{CO}_{2}\right]$ than $\mathrm{C} 3$ species (Ainsworth \& Rogers, 2007; Hatfield et al., 2011). Therefore, corn would instead respond more strongly to other environmental characteristics of the exhaust vent air such as temperature (Ainsworth \& Rogers, 2007; Leakey et al., 2004; Long et al., 2006).

\subsubsection{Experimental Treatment and Garden Set Up}

Test gardens were built around the two Direct Drive Centrifugal Roof Exhausters that were actively and continuously exhausting air on the rooftop and the two control fans. The control fans tested the effect of the fans alone without exhaust vent air from inside of the building. Hereafter these treatments are called Exhaust Vents and Control Fans. During the test period, daytime conditions from the exhaust vent were similar to indoor air and different from daytime conditions at the control fan as shown by $\left[\mathrm{CO}_{2}\right]$, temperature, and relative humidity 
measurements (Figure S1) taken with the Onset $\mathrm{HOBO}$ sensors described above. For $\left[\mathrm{CO}_{2}\right]$ the daytime measurements averaged $758 \pm 3.7 \mathrm{ppm}$ at the Exhaust Vents, $512 \pm 2.8 \mathrm{ppm}$ Inside, and $454 \pm 2.5 \mathrm{ppm}$ at the Control Fan. None of the $95 \%$ confidence intervals for the Exhaust Vent (765.1-751.0), Indoor measurements (517.6-506.8), and Control Fan (459.4-450.0) overlapped though the Exhaust Vent was most different being $67 \%$ higher than the Control Fan compared to Indoor measurements being $13 \%$ higher than the Control Fan. For temperature, the daytime measurements averaged $72 \pm 0.035{ }^{\circ} \mathrm{F}$ at the Exhaust Vent, $70 \pm 0.032{ }^{\circ} \mathrm{F}$ Inside, and $58 \pm 0.24{ }^{\circ} \mathrm{F}$ at the Control Fan. Since these measurements were taken in the fall, indoor temperatures were higher at the Exhaust Vent and Inside to compensate for cold outdoor temperatures. Confidence intervals for the Exhaust Vent (72.29-72.16), Inside (69.98-69.86), and Control Fans (58.3257.37) showed a greater difference than with $\mathrm{CO}_{2}$ with Exhaust Vent and Indoor measurements being $25 \%$ and $21 \%$ larger than Control Fan air. For relative humidity, the daytime measurements averaged $45 \% \pm 0.38$ at the Exhaust Vent, $45 \% \pm 0.40$ Inside, and $68 \% \pm 0.45$ at the Control Fan. This was also reflected in the confidence intervals for Exhaust Vent (45.8-44.3), Indoor measurements (45.7-44.1), and Control Fan (68.9-67.1), which overlapped for Exhaust Vent and Indoor measurements and were $33.7 \%$ and $33.9 \%$ over the Control Fan measurements. These differences created the Exhaust Vent treatment experienced by plants grown in the test garden.

In the test gardens, plants were grown in milk cartons, which are large, mobile, and relatively accessible. Milk crates are also the primary container used by current installers of rooftop farms in Boston and across the region, such as Recover Green Roofs (www.recovergreenroofs.com). Recover Green Roofs has developed a RAMM (Recover Aerated Media Module) design with a non-woven Polypropylene Liner with organic compost-based 
potting mix (Recover, 2018). The milk crate and felt portion of Recover Green Roof's RAMMs were graciously lent by Recover Green Roofs to maintain a system similar to other rooftop farms in Boston. Eight of these milk crates were placed in pairs around each of the four sides of each fan for a total of 32 milk crates.

We used an open system to apply the vent air to avoid backpressure. Curved aluminum structures (Figure 1) were attached around the base of the vent to direct the vent air towards the plants. This avoided drying out the planting media, a common issue in rooftop gardens (Ahmed et al., 2017), by aiming the vent air above the media. Soil moisture was measured in each milk crate twice a week using a hand held Soil Moisture Meter (Vegetronix, Digital VG-Meter-200). An anemometer (HOLDPEAK 866B Digital Anemometer Handheld) was used to determine the wind speed of the exhaust vents. The wind speeds of the two exhaust vents were approximately 10 and $17 \mathrm{mph}$. It was not possible to change the speed of either of these fans. Therefore, the speed of the two control fans were adjusted to reflect these wind speeds.

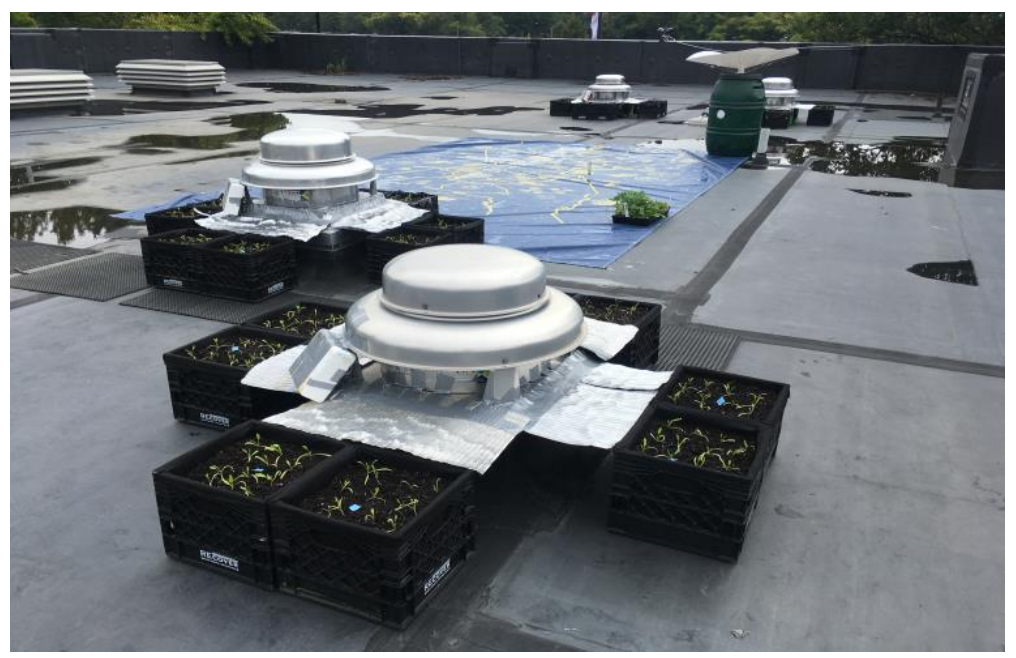

Figure 1. Experimental garden set up around rooftop exhaust vents and control fans. Spinach and corn were planted in milk crates provided by Recover Green Roofs positioned next to various vents for four and a half weeks until harvest after which growth was measured. 


\subsubsection{Plant Growth}

In the fall of 2018, spinach seeds (Bloomsdale, Long standing, USDA organic) were purchased from Mountain Valley Seed Co. and planted in starter trays for four weeks in a classroom in BUA with a large south facing window. They were watered from above approximately every other day until ready to be transplanted on the roof. Plants were hardened for a week before being transplanted by being moved onto the rooftop for increasing amounts of time. The sprouts were then moved permanently up to the rooftop and 12 spinach plants, three rows of four, were planted in each of the 32 boxes. The experiment produced a total of 384 plants with 96 in each of four treatments, with each treatment distributed among 8 boxes. In spring 2019, the same experiment was done except with corn seeds (Trinity Organic F1) purchased from Johnny's Selected Seeds (Winslow, ME). Nine corn sprouts, three rows of three, were planted in 12 boxes for a total of 81 plants, 27 in each treatment. This represents pseudo replication with multiple plants and boxes surrounding only two exhaust vents and two control fans, each with a different wind speed (Ellsworth et al., 1996). In the spring only the low wind speed exhaust vent and control fan was used along with a second control group where the fan was not turned on to further test the effect of the wind speed on the plants. Spring measurements were done to gain a preliminary understanding of whether environmental factors besides $\left[\mathrm{CO}_{2}\right]$ such as temperature contributed to the growth effect on plants.

Nature's Care potting soil, and organic, compost-based soil similar to the potting mix in the Recover Green Roof RAMM system was used. After one full day outside, the boxes were moved a foot away from the edge of the vents and fans at the end of the metal sheets directing the air. Plants were watered approximately every other day once it had not rained for three consecutive days. 


\subsubsection{Crop Performance}

Every 10 days one row of three plants was harvested. Plants were cut at the base just below the soil surface and immediately weighed to measure the wet weight of biomass. All plants were then frozen and kept at $-80^{\circ} \mathrm{C}$ until they were placed within a lyophilizer and dried for three days. At the end of this, plants were again weighed to find the dry weight of biomass. In the fall, three harvests were carried out a week and a half apart and in the spring all plants were harvested at the end of the four and a half weeks. Each week the number of leaves was counted on each plant. A leaf was counted once it had unfolded and the petiole could be seen extending from the center of the spinach plant.

\subsection{Statistical Analysis}

All statistical analyses and data visualization were performed in $\mathrm{R}$ (Version 3.4.4). For a subset of the classrooms in CAS (Rooms B08A, 114B, 201, 213, and 315) where $\left[\mathrm{CO}_{2}\right]$ was measured, the scheduling data were merged with the $\left[\mathrm{CO}_{2}\right]$ data. The class times were then highlighted on the $\left[\mathrm{CO}_{2}\right]$ graphs in order to determine overlap of $\left[\mathrm{CO}_{2}\right]$ spikes and class times. Since people are mostly present in school buildings and plants primarily undergo photosynthesis during the day, the $\mathrm{CO}_{2}$ and environmental conditions between 8:00 am and 4:00 pm were isolated and further analyses were conducted on this subset of data.

Overall effects of the different treatments of air from exhaust vents and control fans on the wet and dry biomass and leaf number of the crops were analyzed with an ANOVA with each plant as the experimental unit. The treatment was the independent variable and the biomass or leaf number the dependent variable. The multiple comparisons using least squares means Tukey's HSD method was used to identify significant differences between treatments. This same analysis 
was done to determine differences between the effect of different speeds at the four fans. An ANOVA was used for analysis of the environmental characteristics though averaging environmental data over time ignores non-linear impacts on trends. To further characterize these data, $95 \%$ confidence intervals and effect size were also calculated.

\section{Acknowledgments}

There were no conflicts of interest for any author. The data supporting the conclusions can be obtained in the references and supporting information. This material is based upon work supported by the National Science Foundation Graduate Research Fellowship under Grant No. DGE-1840990 as well as partially funded by NSF Grant \#1617053. We would also like to thank the Boston University Pardee Center, Boston University's Initiative on Cities, and the Boston University Urban Biogeosciences and Environmental Health Program for their financial support of this project. Data will be made available by acceptance in CIARD Ring a global repository containing dataset for agricultural research for development (ARD). We would also like to thank Sidney Hare, Betsy Cowdery, Finn Stirling, and Tony Pham for their assistance collecting samples. The entire community at the Boston University Academy, especially Paige Brewster,

Travis Bain, and Cynthia Taylor, also were essential in carrying out this project.

\section{References}

ACGIH (American Conference of Governmental Industrial Hygienists). (2011). TLVs and BEIs. Cincinnati, OH:American Conference of Governmental Industrial Hygienists.

Ahmed, S., Buckley, S., Stratton, A. E., Asefaha, F., Butler, C., Reynolds, M., \& Orians, C. (2017). Sedum groundcover variably enhances performance and phenolic concentrations of perennial culinary herbs in an urban edible green roof. Agroecology and Sustainable Food Systems, 41(5). https://doi.org/10.1080/21683565.2017.1279703

Ainsworth, E. A., Leakey, A. D. B., Ort, D. R., \& Long, S. P. (2008). FACE-ing the facts: inconsistencies and interdependence among field, chamber and modeling studies of elevated [CO2] impacts on crop yield and food supply. New Phytologist, 179, 5-9.

Ainsworth, E. A., \& Long, S. P. (2005). What have we learned from 15 years of free-air CO2 
enrichment (FACE)? A meta-analytic review of the responses of photosynthesis, canopy properties and plant production to rising CO2. New Phytologist, 165, 351-372.

Ainsworth, E. A., \& Rogers, A. (2007). The response of photosynthesis and stomatal conductance to rising [CO 2]: Mechanisms and environmental interactions. Plant, Cell and Environment, 30(3), 258-270. https://doi.org/10.1111/j.1365-3040.2007.01641.x

Allen, J. G., MacNaughton, P., Satish, U., Santanam, S., Vallarino, J., \& Spengler, J. D. (2016). Associations of cognitive function scores with carbon dioxide, ventilation, and volatile organic compound exposures in office workers: A controlled exposure study of green and conventional office environments. Environmental Health Perspectives, 124(6), 805-812. https://doi.org/10.1289/ehp.1510037

Apte, M. G., Fisk, W. J., \& Daisey, J. M. (2000a). Associations Between Indoor CO2 Concentrations and Sick Building Syndrome Symptoms in U.S. Office Buildings: An Analysis of the 1994-1996 BASE Study Data. Indoor Air, 10(4), 246-257. https://doi.org/10.1034/j.1600-0668.2000.010004246.x

Apte, M. G., Fisk, W. J., \& Daisey, J. M. (2000b). Associations Between Indoor CO2 Concentrations and Sick Building Syndrome Symptoms in US Office Buildings: An Analysis of the 1994 - 1996 BASE Study Data. Indoor Air, 10, 246-257.

ArrowStreet Architecture \& Design. (2016). Addressing Campus Sustainability through MIT 's Roofscapes.

Bang, C., Sabo, J. L., \& Faeth, S. H. (2010). Reduced wind speed improves plant growth in a desert city. PLoS ONE, 5(6), e11061. https://doi.org/10.1371/journal.pone.0011061

Batchelor, J., Spang, L. S., \& Soo Hoo, T. (2009). Green Roof Planning Study.

Boese, S. R., \& Huner, N. P. A. (1990). Effect of growth temperature and temperature shifts on spinach leaf morphology and photosynthesis. Plant Physiology, 94(4), 1830-1836. https://doi.org/10.1104/pp.94.4.1830

Bounoua, L., Zhang, P., Mostovoy, G., Thome, K., Masek, J., Imhoff, M., ... Toure, A. M. (2015). Impact of urbanization on US surface climate. Environmental Research Letters, 10(8), 1-9. https://doi.org/10.1088/1748-9326/10/8/084010

Briber, B. M., Hutyra, L. R., Reinmann, A. B., Raciti, S. M., Dearborn, V. K., Holden, C. E., \& Dunn, A. L. (2015). Tree productivity enhanced with conversion from forest to urban land covers. PLoS ONE, 10(8), 1-19. https://doi.org/10.1371/journal.pone.0136237

Bunea, A., Andjelkovic, M., Socaciu, C., Bobis, O., Neacsu, M., Verhe, R., \& Camp, J. Van. (2008). Total and individual carotenoids and phenolic acids content in fresh, refrigerated and processed spinach (Spinacia oleracea L .). Food Chemistry, 108, 649-656. https://doi.org/10.1016/j.foodchem.2007.11.056

Cai, C., Yin, X., He, S., Jiang, W., Si, C., Struik, P. C., ... Pan, G. (2016). Responses of wheat and rice to factorial combinations of ambient and elevated $\mathrm{CO} 2$ and temperature in FACE experiments. Global Change Biology, 22(2), 856-874. https://doi.org/10.1111/gcb.13065

Calfapietra, C., Ainsworth, E. A., Beier, C., De Angelis, P., Ellsworth, D. S., Godbold, D. L., ... Ceulemans, R. (2010). Challenges in elevated CO2 experiments on forests. Trends in Plant Science, 15(1), 5-10. https://doi.org/10.1016/j.tplants.2009.11.001 
Candlish, J. K., Gourley, L., \& Lee, H. P. (1987). Dietary Fiber and Starch Contents of Some Southeast Asian Vegetables. Journal of Agricultural and Food Chemistry, 35(3), 319-321. https://doi.org/10.1021/jf00075a008

Carter, T. L., \& Rasmussen, T. C. (2007). Hydrologic Behavior of Vegetated Roofs. Journal of the American Water Resources Association, 42(5), 1261-1274. https://doi.org/10.1111/j.1752-1688.2006.tb05611.x

Chakrabarti, B., Singh, S. D., Naresh Kumar, S., Aggarwal, P. K., Pathak, H., \& Nagarajan, S. (2012). Low-cost facility for assessing impact of carbon dioxide on crops. Current Science, 102(7), 1035-1040.

Davies, Z. G., Edmondson, J. L., Heinemeyer, A., Leake, J. R., \& Gaston, K. J. (2011). Mapping an urban ecosystem service: quantifying above-ground carbon storage at a city-wide scale. Journal of Applied Ecology, 48, 1125-1134. https://doi.org/10.1111/j.13652664.2011.02021.x

Decina, S. M., Hutyra, L. R., Gately, C. K., Getson, J. M., Reinmann, A. B., Short Gianotti, A. G., \& Templer, P. H. (2016). Soil respiration contributes substantially to urban carbon fluxes in the greater Boston area. Environmental Pollution, 212, 433-439. https://doi.org/10.1016/j.envpol.2016.01.012

Deng, A., \& Stauffer, D. R. (2006), On improving 4-km mesoscale model simulations. Journal of Applied Meteorology and Climatology, 45(3), 361-381. doi:10.1175/JAM2341.1

Dentener, F. J., Easterling, D. R., Uk, R. A., Uk, R. A., Cooper, O., Canada, F., ... Morice, C. (2013). Observations: Atmosphere and Surface, IPCC 2013.

Edwards, G. R., Clark, H., \& Newton, P. C. D. (2001). The effects of elevated CO2 on seed production and seedling recruitment in a sheep-grazed pasture. Oecologia, 127(3), 383-394. https://doi.org/10.1007/s004420000602

Ellsworth, D. S., Oren, R., Huang, C., Phillips, N., \& Hendrey, G. R. (1996). Erratum: Leaf and canopy responses to elevated $\mathrm{CO} 2$ in a pine forest under free-air $\mathrm{CO} 2$ enrichment (Oecologia (1995) 104 (139-146)). Oecologia, 106(3), 416. https://doi.org/10.1007/BF00334570

Elmes, A., Rogan, J., Williams, C., Ratick, S., Nowak, D., \& Martin, D. (2017). Effects of urban tree canopy loss on land surface temperature magnitude and timing. ISPRS Journal of Photogrammetry and Remote Sensing, 128, 338-353. https://doi.org/10.1016/j.isprsjprs.2017.04.011

Garrison, N., Horowitz, C., \& Lunghino, C. A. (2012). Looking Up: How Green Roofs and Cool Roofs Can Reduce Energy Use, Address Climate Change, and Protect Water Resources in Southern California. NRDC Report, R:12-06-B(June), 1-33. https://doi.org/10.1109/TDC.2005.1547154

Getter, K., Rowe, D., \& Robertson, G. (2009). Carbon sequestration potential of extensive green roofs. Science \& Technology, 43(19), 7564-7570. Retrieved from http://pubs.acs.org/doi/abs/10.1021/es901539x

Guite, H. F., Clark, C., \& Ackrill, G. (2006). The impact of the physical and urban environment on mental well-being. Public Health, 120(12), 1117-1126. 
https://doi.org/10.1016/j.puhe.2006.10.005

Halwell, B. (2002). Home Grown The Case for Local Food in a Global Market.

Hanson, P. J., Edwards, N. T., Garten, C. T., \& Andrews, J. A. (2000). Separating root and soil microbial contributions to soil respiration : A review of methods and observations. Biogeochemistry, 48, 115-146.

Hatfield, J. L., Boote, K. J., Kimball, B. A., Ziska, L. H., Izaurralde, R. C., Ort, D., ... Wolfe, D. (2011). Climate impacts on agriculture: Implications for crop production. Agronomy Journal, 103(2), 351-370. https://doi.org/10.2134/agronj2010.0303

He, Y., Yu, H., Dong, N., \& Ye, H. (2016). Thermal and energy performance assessment of extensive green roof in summer: A case study of a lightweight building in Shanghai. Energy and Buildings, 127, 762-773. https://doi.org/10.1016/j.enbuild.2016.06.016

Hendrey, G., Lewin, K., \& Nagy, J. (1993). Free Air Carbon Dioxide Enrichment: Development, Progress, Results. Vegetatio, 104(Jan), 16-31.

Howard, L. R., Pandjaitan, N., Morelock, T., \& Gil, M. I. (2005). Antioxidant capacity and phenolic content of spinach as affected by genetics and maturation. Journal of Agricultural and Food Chemistry, 53(22), 8618-8623. https://doi.org/10.1021/jf052077i

Idso, S. B., \& Idso, K. E. (2001). Effects of atmospheric CO(2) enrichment on plant constituents related to animal and human health. Environmental and Experimental Botany. https://doi.org/10.1016/S0098-8472(00)00091-5

Ismail, A., Abdul Samad, M. H., Rahman, A. M. A., \& Yeok, F. S. (2012). Cooling Potentials and CO2 Uptake of Ipomoea Pes-caprae Installed on the Flat Roof of a Single Storey Residential Building in Malaysia. Procedia - Social and Behavioral Sciences, 35(December), 361-368. https://doi.org/10.1016/j.sbspro.2012.02.099

Ito, K., Nardi, C., \& Vuong, T. (2015). Planning Urban Heat Island Mitigation. https://doi.org/10.1093/icesjms/fss088

Jin, M., Bekiaris-Liberis, N., Weekly, K., Spanos, C., \& Bayen, A. (2015). Sensing by Proxy: Occupancy Detection Based on Indoor CO2 Concentration Ming. In UMBICOMM 2015: The Ninth International Conference onMobile Ubiquitous Computing, Systems, Services and Technologies (pp. 1-10).

Johnson, B. S., Malecki, K. M., Peppard, P. E., \& Beyer, K. M. M. (2018). Exposure to neighborhood green space and sleep: evidence from the Survey of the Health of Wisconsin. Sleep Health, 4(5), 413-419. https://doi.org/10.1016/j.sleh.2018.08.001

Kadam, K. L., \& McMillan, J. D. (2003). Availability of corn stover as a sustainable feedstock for bioethanol production. Bioresource Technology, 88(1), 17-25. https://doi.org/10.1016/S0960-8524(02)00269-9

Kangasjärvi, J., Jaspers, P., \& Kollist, H. (2005). Signalling and cell death in ozone-exposed plants. Plant, Cell and Environment, 28(8), 1021-1036. https://doi.org/10.1111/j.13653040.2005.01325.x

Kimball, B., Kobayashi, K., \& Bindi, M. (2002). Responses of agricultural crops to free-air CO 2 enrichment. Advances in Agronomy. https://doi.org/10.1016/S0065-2113(02)77017-X 
Kleerekoper, L., Van Esch, M., \& Salcedo, T. B. (2012). How to make a city climate-proof, addressing the urban heat island effect. Resources, Conservation and Recycling, 64, 30-38. https://doi.org/10.1016/j.resconrec.2011.06.004

Kuti, J. O., \& Konuru, H. B. (2004). Antioxidant Capacity and Phenolic Content in Leaf Extracts of Tree Spinach (Cnidoscolus spp.). Journal of Agricultural and Food Chemistry, 52(1), 117-121. https://doi.org/10.1021/jf030246y

Leakey, A. D. B., Ainsworth, E. A., Bernacchi, C. J., Rogers, A., Long, S. P., \& Ort, D. R. (2009). Elevated CO2 effects on plant carbon, nitrogen, and water relations: six important lessons from FACE. Journal of Experimental Botany, 60(10), 2859-2876. https://doi.org/10.1093/jxb/erp096

Leakey, A. D. B., Bernacchi, C. J., Dohleman, F. G., Ort, D. R., \& Long, S. P. (2004). Will photosynthesis of maize (Zea mays) in the US Corn Belt increase in future [CO2] rich atmospheres? An analysis of diurnal courses of $\mathrm{CO} 2$ uptake under free-air concentration enrichment (FACE). Global Change Biology, 10(6), 951-962. https://doi.org/10.1111/j.1529-8817.2003.00767.x

Lee, S. C., \& Chang, M. (1999). Indoor air quality investigations at five classrooms. Indoor Air, 9(2), 134-138. https://doi.org/10.1111/j.1600-0668.1999.t01-2-00008.x

Loladze, I. (2002). Rising atmospheric CO2and human nutrition: Toward globally imbalanced plant stoichiometry? Trends in Ecology and Evolution, 17(10), 457-461. https://doi.org/10.1016/S0169-5347(02)02587-9

Long, S. P., Ainsworth, E. A., Leakey, A. D. B., Nosberger, J., \& Ort, D. R. (2006). Food for Thought : Lower-Than-Expected Crop Yield Stimulation with Rising CO2 Concentrations. Science, 312(June), 1918-1922.

Long, S. P., Ainsworth, E. A., Rogers, A., \& Ort, D. R. (2004). Rising Atmospheric Carbon Dioxide: Plants FACE the Future. Annual Review of Plant Biology, 55, 591-628. https://doi.org/10.1146/annurev.arplant.55.031903.141610

Lower, E., \& Dining, D. (2014). Case Study: economic viability of growing produce organically on-site at restaurants, $1-5$.

McLeod, A. R., \& Long, S. P. (1999). Free-air Carbon Dioxide Enrichment (FACE) in Global Change Research: A Review. Advances in Ecological Research, 28, 1-57.

Medek, D. E., Schwartz, J., \& Myers, S. S. (2017). Estimated Effects of Future Atmospheric $\mathrm{CO} 2$ Concentrations on Protein Intake and the Risk of Protein Deficiency by Country and Region. Environmental Health Perspectives, 125(8), 1-8. https://doi.org/10.1289/EHP41

Meier, A. K. (1990). Strategic landscaping and air-conditioning savings: A literature review. Energy and Buildings, 15(3-4), 479-486. https://doi.org/10.1016/0378-7788(90)90024-D

Memon, R. A., Leung, D. Y., \& Chunho, L. (2008). A review on the generation, determination and mitigation of Urban Heat Island. Journal of Environmental Sciences, 20, 120-128.

Miglietta, F., Lanini, M., Bindi, M., \& Magliulo, V. (1997). Free Air CO2 Enrichment of potato (Solanum tuberosum, L.): design and performance of the $\mathrm{CO} 2$-fumigation system. Global Change Biology, 3(5), 417-427. https://doi.org/doi:10.1046/j.1365-2486.1997.00076.x 
Min, K. (2014). Effect of short-term versus prolonged freezing on freeze-thaw injury and postthaw recovery in spinach: Importance in laboratory freeze-thaw protocols. Environmental and Experimental Botany, 1-63. https://doi.org/10.1016/j.envexpbot.2014.01.009

Mohajerani, A., Bakaric, J., \& Jeffrey-Bailey, T. (2017). The urban heat island effect, its causes, and mitigation, with reference to the thermal properties of asphalt concrete. Journal of Environmental Management, 197, 522-538. https://doi.org/10.1016/j.jenvman.2017.03.095

Moore, B. D., Cheng, S., Sims, D., \& Seemann, J. R. (1999). The biochemical and molecular basis for photosynthetic acclimation to elevated atmospheric CO2. Plant, Cell and Environment, 22, 567-582.

Myers, S. S., Zanobetti, A., Kloog, I., Huybers, P., Leakey, A. D. B., Bloom, A. J., ... Usui, Y. (2014). Increasing CO2 threatens human nutrition. Nature, 510(7503), 139-142. https://doi.org/10.1038/nature13179

Myhrvold, A. N., Olsen, E., \& Lauridsen, Ø. (1996). Indoor environment in schools - Pupils' health and performance in regard to $\mathrm{CO} 2$ concentration. Indoor Air 96.

Nagase, A., \& Dunnett, N. (2012). Amount of water runoff from different vegetation types on extensive green roofs: Effects of plant species, diversity and plant structure. Landscape and Urban Planning, 104(3-4), 356-363. https://doi.org/10.1016/j.landurbplan.2011.11.001

Ng, C. W. W., Tasnim, R., \& Wong, J. T. F. (2019). Coupled effects of atmospheric CO2 concentration and nutrients on plant-induced soil suction. Plant Soil, 439(1-2), 393-404. https://doi.org/10.1007/s11104-019-04047-4

Ngan, G. (2004). Green Roof Policies: Tools for Encouraging Sustainable Design. Retrieved from http://www.igra-world.com/green_roof_policies/index.php

Nijs, I., Ferris, R., Blum, H., Hendrey, G., \& Impens, I. (1997). Stomatal regulation in a changing climate: A field study using free air temperature increase (FATI) and free air CO2 enrichment (FACE). Plant, Cell and Environment, 20(8), 1041-1050. https://doi.org/10.1111/j.1365-3040.1997.tb00680.x

Nitsch, E. (2016). Harvard Business School Stormwater Plan Update.

Norby, R. J., \& Zak, D. R. (2011). Ecological Lessons from Free-Air CO2 Enrichment (FACE) Experiments. The Annual Review of Ecology, Evolution, and Systematics, 42(September), 181-203. https://doi.org/10.1146/annurev-ecolsys-102209-144647

Nowak, R. S., Ellsworth, D. S., \& Smith, S. D. (2004). Functional responses of plants to elevated atmospheric CO2 - Do photosynthetic and productivity data from FACE experiments support early predictions? New Phytologist, 162(2), 253-280. https://doi.org/10.1111/j.1469-8137.2004.01033.x

Nuutila, A. M. (2002). Comparison of methods for the hydrolysis of flavonoid and phenolic acids from onion and spinach for HPLC analysis. Food Chemistry, 76(April), 519-525. https://doi.org/10.1016/S0308-8146(01)00305-3

Oberndorfer, E., Lundholm, J., Bass, B., Coffman, R. R., Doshi, H., Dunnett, N., ... Rowe, B. (2007). Green Roofs as Urban Ecosystems: Ecological Structures, Functions, and Services. BioScience, 57(10), 823. https://doi.org/10.1641/B571005 
Onoda, Y., \& Anten, N. P. R. (2011). Challenges to understand plant responses to wind. Plant Signaling and Behavior, 6(7), 139-141. https://doi.org/10.4161/psb.6.7.15635

Orsini, F., Gasperi, D., Marchetti, L., Piovene, C., Draghetti, S., Ramazzotti, S., ... Gianquinto, G. (2014). Exploring the production capacity of rooftop gardens (RTGs) in urban agriculture: the potential impact on food and nutrition security, biodiversity and other ecosystem services in the city of Bologna. Food Security, 6(6), 781-792. https://doi.org/10.1007/s12571-014-0389-6

Persily, A., \& de Jonge, L. (2017). Carbon dioxide generation rates for building occupants. Indoor Air, 27(5), 868-879. https://doi.org/10.1111/ina.12383

Pirog, R. S., Van Pelt, T., Enshayan, K., \& Cook, E. (2001). Food, fuel, and freeways: an Iowa perspective on how far food travels, fuel usage, and greenhouse gas emissions. Leopold Center for Sustainable Agriculture, 1-37.

Prajapati, S. K. (2012). Ecological effect of airborne particulate matter on plants. Environmental Skeptics and Critics, 1(1), 12-22. https://doi.org/http://dx.doi.org/10.0000/issn-2224-4263environsc-2012-v1-0003

Raciti, S. M., Hutyra, lucy R., Rao, P., \& Finzi, A. C. (2012). Inconsistent definitions of “، urban " result in different conclusions about the size of urban carbon and nitrogen stocks. Ecological Applications, 22(3), 1015-1035.

Rao, P., Hutyra, L. R., Raciti, S. M., \& Templer, P. H. (2014). Atmospheric nitrogen inputs and losses along an urbanization gradient from Boston to Harvard Forest, MA. Biogeochemistry, 121(1), 229-245. https://doi.org/10.1007/s10533-013-9861-1

Reddy, M. T., Begum, H., Sunil, N., Rao, P. S., Sivaraj, N., \& Kumar, S. (2014). Preliminary Characterization and Evaluation of Landraces of Indian Spinach ( Basella spp. L.) for Agroeconomic and Quality Traits. Plant Breeding and Biotechnology, 2(1), 48-63. https://doi.org/10.9787/pbb.2014.2.1.048

Reece, C. F., Krupa, S. V., Jäger, H. J., Roberts, S. W., Hastings, S. J., \& Oechel, W. C. (1995). Evaluating the effects of elevated levels of atmospheric trace gases on herbs and shrubs: A prototype dual array field exposure system. Environmental Pollution, 90(1), 25-31. https://doi.org/10.1016/0269-7491(94)00095-U

Reinmann, A. B., Hutyra, L. R., Trlica, A., \& Olofsson, P. (2016). Assessing the global warming potential of human settlement expansion in a mesic temperate landscape from 2005 to 2050 . Science of the Total Environment, 545-546, 512-524. https://doi.org/10.1016/j.scitotenv.2015.12.033

Rice, S. A. (2004). Human Health Risk Assessment of CO2: Survirors of Accute High-Level Exposure and Populations Sensitive to Prolonged Low-Level Exposure. Third Annual Conference on Carbon Sequestration, 1-9.

Rogers, H. H., Runion, G. B., \& Krupa, S. v. (1994). Plant reponses to atmospheric CO2 enrichment with emphasis on roots and the rhizosphere. Environmental Pollution, 83, 155189. https://doi.org/10.1016/0269-7491(94)90034-5

Roofs, R. G. (2018). RAMM (Recover Aerated Media Module) Product Description.

Roulet, C. A., \& Foradini, F. (2002). Simple and Cheap Air Change Rate Measurement Using 
CO2 Concentration Decays. International Journal of Ventilation, 1(1), 1-7.

Rowe, D. B. (2011). Green roofs as a means of pollution abatement. Environmental Pollution, 159(8-9), 2100-2110. https://doi.org/10.1016/j.envpol.2010.10.029

Saadatian, O., Sopian, K., Salleh, E., Lim, C. H., Riffat, S., Saadatian, E., ... Sulaiman, M. Y. (2013). A review of energy aspects of green roofs. Renewable and Sustainable Energy Reviews, 23, 155-168.

Santamouris, M. (2014). Cooling the cities - A review of reflective and green roof mitigation technologies to fight heat island and improve comfort in urban environments. Solar Energy, 103, 682-703. https://doi.org/10.1016/j.solener.2012.07.003

Satish, U., Mendell, M. J., Shekhar, K., Hotchi, T., Sullivan, D., Streufert, S., \& Fisk, W. J. (2012). Is CO2 an Indoor Pollutant? Direct Effects of Low-to-Moderate CO2 Concentrations on Human Decision-Making Performance. Environmental Health Perspectives, 120(12), 1671-1677.

Satish, U., Mendell, M. J., Shekhar, K., Sullivan, D., Streufert, S., \& Fisk, W. J. (2012). Is CO2 an Indoor Pollutant? Direct Effects of Low to Moderate CO2 Concentrations on Human Decision Making Performance. Environmental Health Perspectives, doi:10.1289/ehp.1104789. https://doi.org/10.1289/ehp.1104789

Seppanen, O. A., Fisk, W. J., \& Mendell, M. J. (1999). Association of Ventilation Rates and $\mathrm{CO} 2$ Concentrations with Health andOther Responses in Commercial and Institutional Buildings. Indoor Air, 9(4), 226-252. https://doi.org/10.1111/j.1600-0668.1999.00003.x

Seto, K. C., Güneralp, B., \& Hutyra, L. R. (2012). Global forecasts of urban expansion to 2030 and direct impacts on biodiversity and carbon pools. Proceedings of the National Academy of Sciences of the United States of America, 109(40), 16083-16088. https://doi.org/10.1073/pnas.1211658109

Shafique, M., \& Kim, R. (2017). Retrofitting the Low Impact Development Practices into Developed Urban areas Including Barriers and Potential Solution. Open Geosciences, 9(1), 240-254. https://doi.org/10.1515/geo-2017-0020

Shafique, M., Kim, R., \& Kyung-Ho, K. (2018). Green roof for stormwater management in a highly urbanized area: The case of Seoul, Korea. Sustainability (Switzerland), 10(3). https://doi.org/10.3390/su10030584

Shafique, M., Xue, X., \& Luo, X. (2020). An overview of carbon sequestration of green roofs in urban areas. Urban Forestry and Urban Greening. https://doi.org/10.1016/j.ufug.2019.126515

Sharkey, T. D. (1988). Estimating the rate of photorespiration in leaves. Plant Physiology, 73, $147-152$.

Shohag, M. J. I., Wei, Y., Yu, N., Zhang, J., Wang, K., Patring, J., .. Yang, X. (2011). Natural Variation of Folate Content and Composition in Spinach (Spinacia oleracea) Germplasm. Journal of Agricultural and Food Chemistry, 59, 12520-12526.

Stathopoulou, M., \& Cartalis, C. (2007). Daytime urban heat islands from Landsat ETM+ and Corine land cover data: An application to major cities in Greece. Solar Energy, 81(3), 358368. https://doi.org/10.1016/j.solener.2006.06.014 
Templer, P. H., Toll, J. W., Hutyra, L. R., \& Raciti, S. M. (2015). Nitrogen and carbon export from urban areas through removal and export of litterfall. Environmental Pollution, 197, 256-261. https://doi.org/10.1016/j.envpol.2014.11.016

Tongson, E., Alejo, L., \& Balderama, O. (2017). Simulating impacts of El Niño and climate change on corn yield in Isabela, Philippines. Climate, Disaster and Development Journal, 02(February), 29-39. https://doi.org/10.18783/cddj.v002.i01.a04

Toudeshki, A., Saadatian, E., Riffat, S., Sopian, K., Sulaiman, M. Y., Salleh, E., ... Lim, C. H. (2013). A review of energy aspects of green roofs. Renewable and Sustainable Energy Reviews, 23, 155-168. https://doi.org/10.1016/j.rser.2013.02.022

Trlica, A., Hutyra, L. R., Schaaf, C. L., Erb, A., \& Wang, J. A. (2017). Albedo, Land Cover, and Daytime Surface Temperature Variation Across an Urbanized Landscape. Earth's Future, 5(11), 1084-1101. https://doi.org/10.1002/2017EF000569

UN. (2014). World Urbanization Prospects: The 2014 Revision, Highlights. Demographic Research (Vol. 12). https://doi.org/10.4054/DemRes.2005.12.9

US EPA. (2008). Reducing Urban Heat Islands: Compendium of Strategies. Cool Pavements. https://doi.org/10.1175/1520-0450(2002)041<0792:THFIUA>2.0.CO;2

Vaughan, N. E., \& Lenton, T. M. (2011). A review of climate geoengineering proposals. Climatic Change, 109, 745-790. https://doi.org/10.1007/s10584-011-0027-7

Whittinghill, L. J., Rowe, D. B., Andresen, J. A., \& Cregg, B. M. (2015). Comparison of stormwater runoff from sedum, native prairie, and vegetable producing green roofs. Urban Ecosystems, 18(1), 13-29. https://doi.org/10.1007/s11252-014-0386-8

Whittinghill, L. J., Rowe, D. B., Schutzki, R., \& Cregg, B. M. (2014). Quantifying carbon sequestration of various green roof and ornamental landscape systems. Landscape and Urban Planning, 123, 41-48. https://doi.org/10.1016/j.landurbplan.2013.11.015

Wong, N. ., Cheong, D. K. ., Yan, H., Soh, J., Ong, C. L., \& Sia, A. (2003). The effects of rooftop garden on energy consumption of a commercial building in Singapore. Energy and Buildings, 35(4), 353-364. https://doi.org/10.1016/s0378-7788(02)00108-1

Yamori, W., Suzuki, K., Noguchi, K., Nakai, M., \& Terashima, I. (2006). Effects of Rubisco kinetics and Rubisco activation state on the temperature dependence of the photosynthetic rate in spinach leaves from contrasting growth temperatures. Plant, Cell and Environment, 29(8), 1659-1670. https://doi.org/10.1111/j.1365-3040.2006.01550.x

Zhang, X., Chen, X., \& Zhang, X. (2018). The impact of exposure to air pollution on cognitive performance. Proceedings of the National Academy of Science, 115(37), 9193-9197. https://doi.org/10.1073/pnas.1809474115

Ziter, C. D., Pedersen, E. J., Kucharik, C. J., \& Turner, M. G. (2019). Scale-dependent interactions between tree canopy cover and impervious surfaces reduce daytime urban heat during summer. Proceedings of the National Academy of Sciences of the United States of America, 116(15), 7575-7580. https://doi.org/10.1073/pnas.1817561116

Zvereva, E. L., \& Kozlov, M. V. (2006). Consequences of simultaneous elevation of carbon dioxide and temperature for plant-herbivore interactions: A metaanalysis. Global Change Biology, 12(1), 27-41. https://doi.org/10.1111/j.1365-2486.2005.01086.x 
998

999

1000 


\section{Figures}

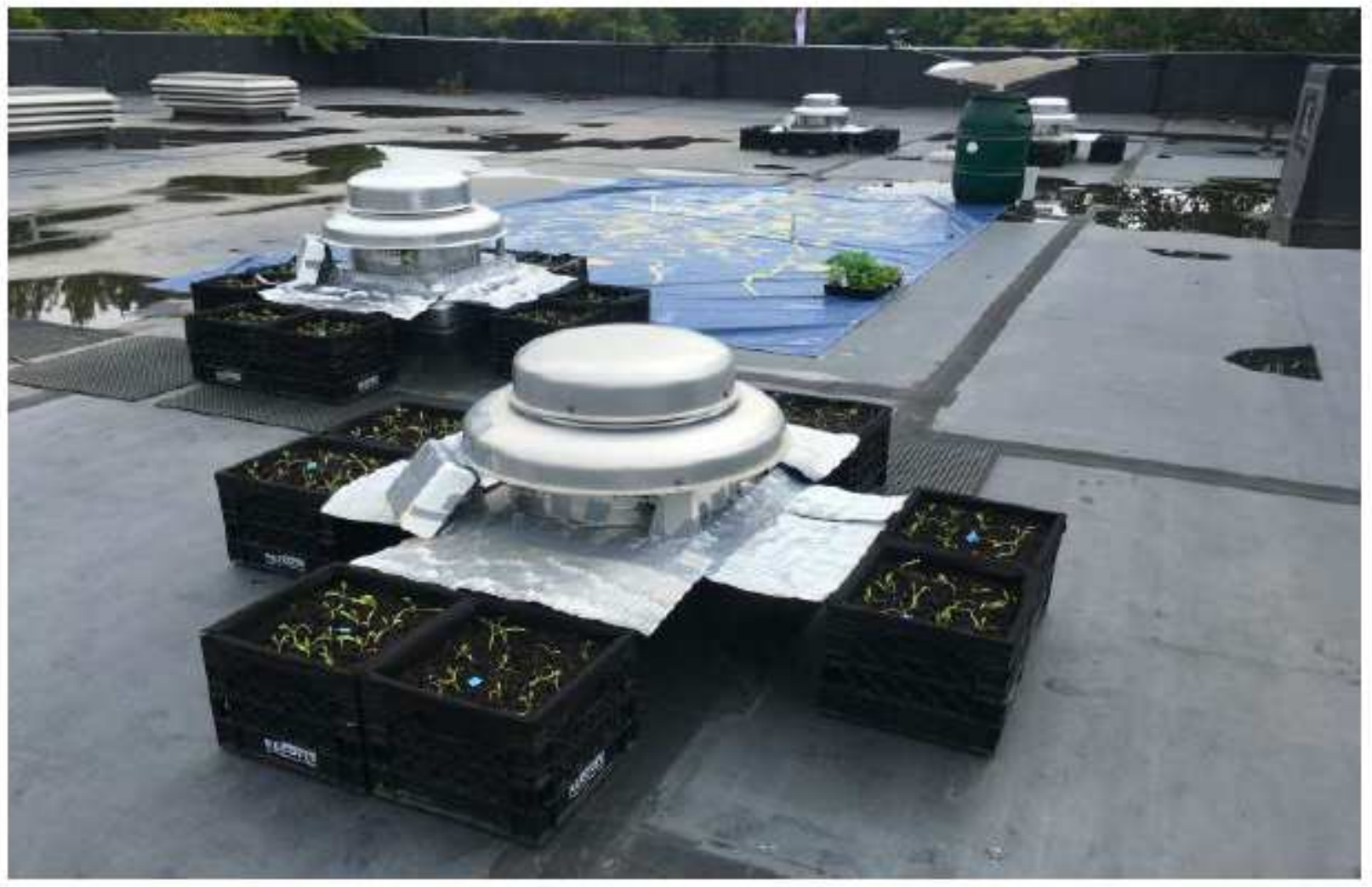

\section{Figure 1}

Experimental garden set up around rooftop exhaust vents and control fans. Spinach and corn were planted in milk crates provided by Recover Green Roofs positioned next to various vents for four and a half weeks until harvest after which growth was measured. 
a)

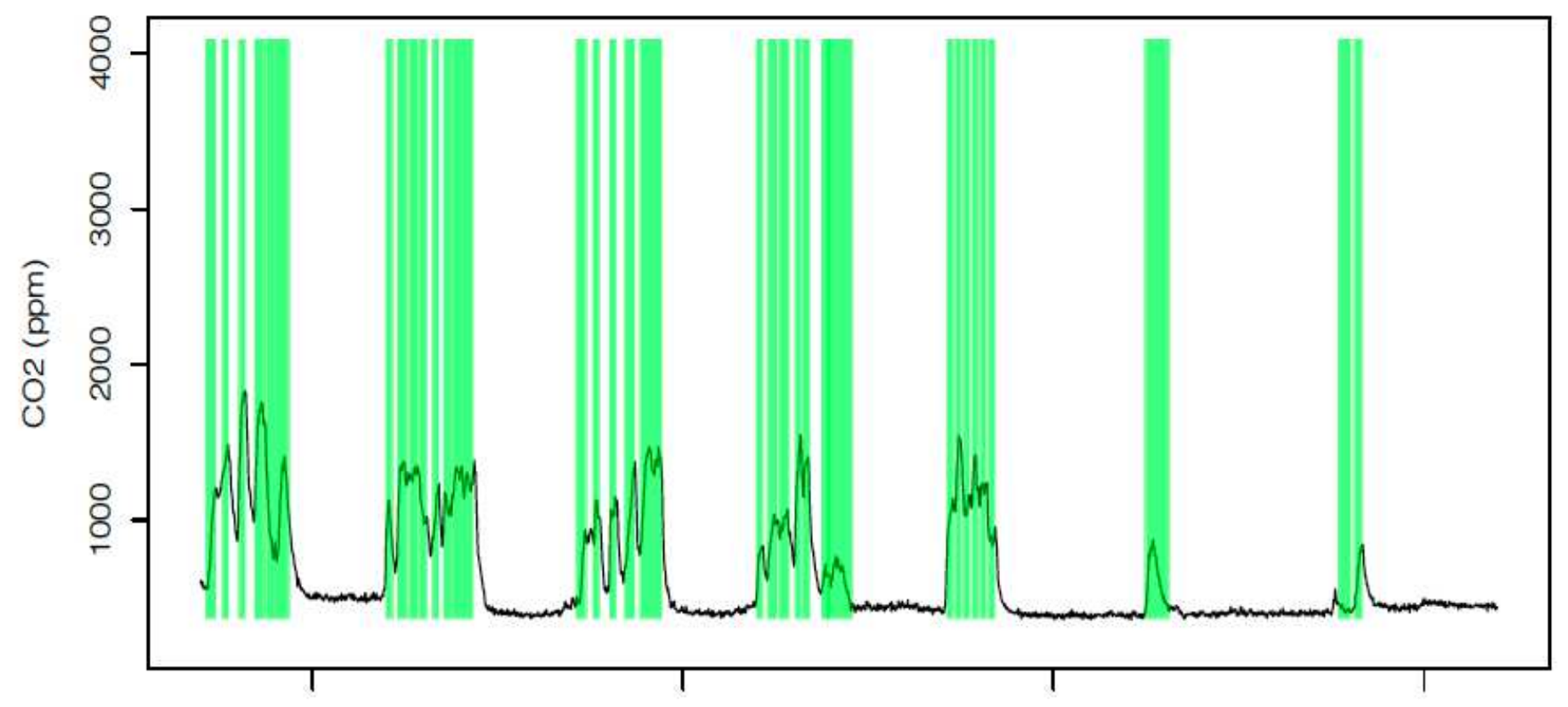

b)

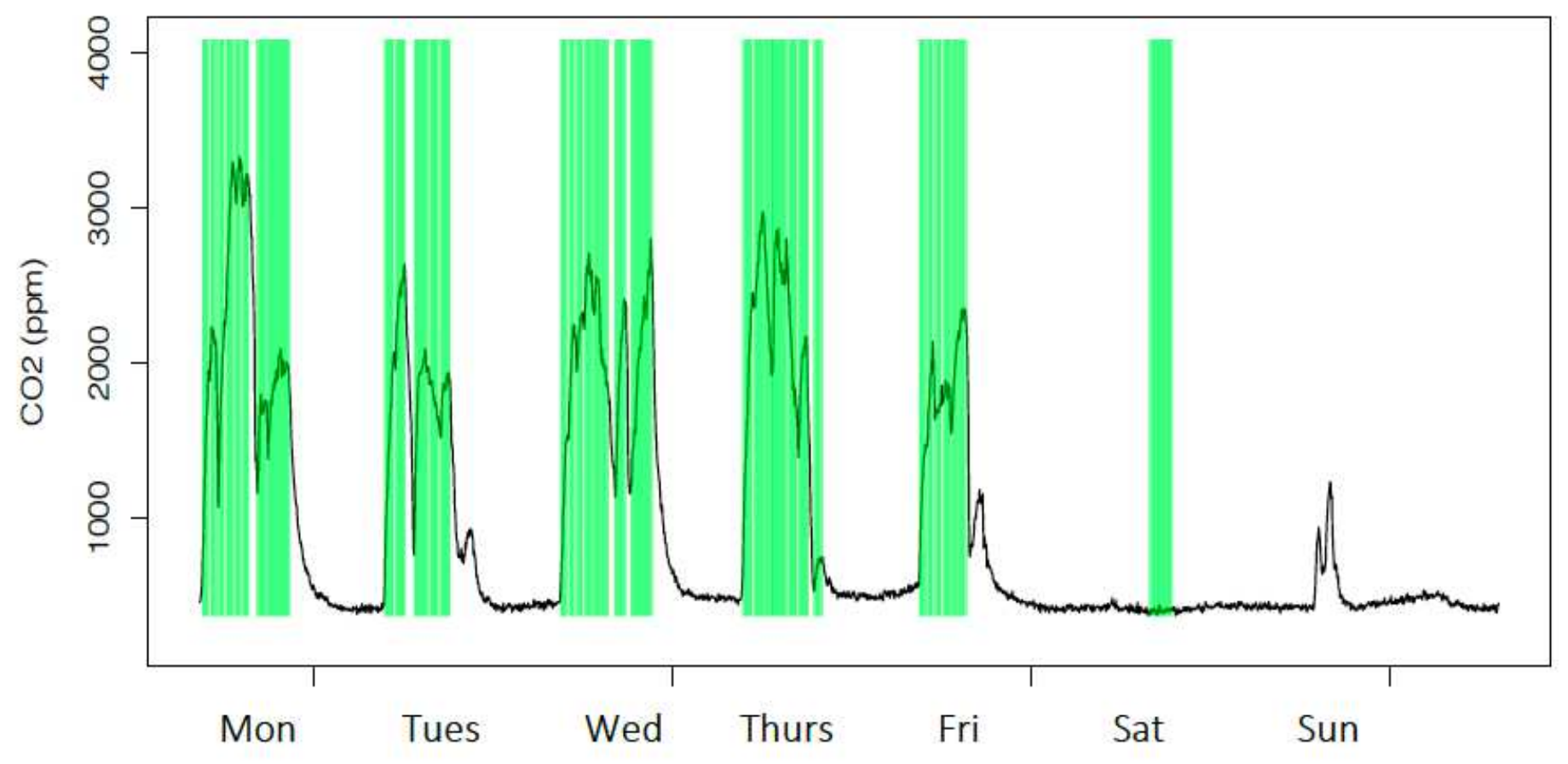

Figure 2

Classroom CO2 measurements and class times. CO2 sensors (Onset HOBO Bluetooth Low Energy Carbon Dioxide - Temp - RH Data Logger, \#MX1102) were installed in classrooms for one week. Occupation data was collected for these classrooms from the 25 Live scheduling system used by BU. Class times (green boxes) were plotted against CO2 concentrations (black lines) over time to compare $\mathrm{CO} 2$ spikes 
with classroom usage. Spikes occurred primarily during class time in classrooms a) CAS 201 and b) CAS 213.
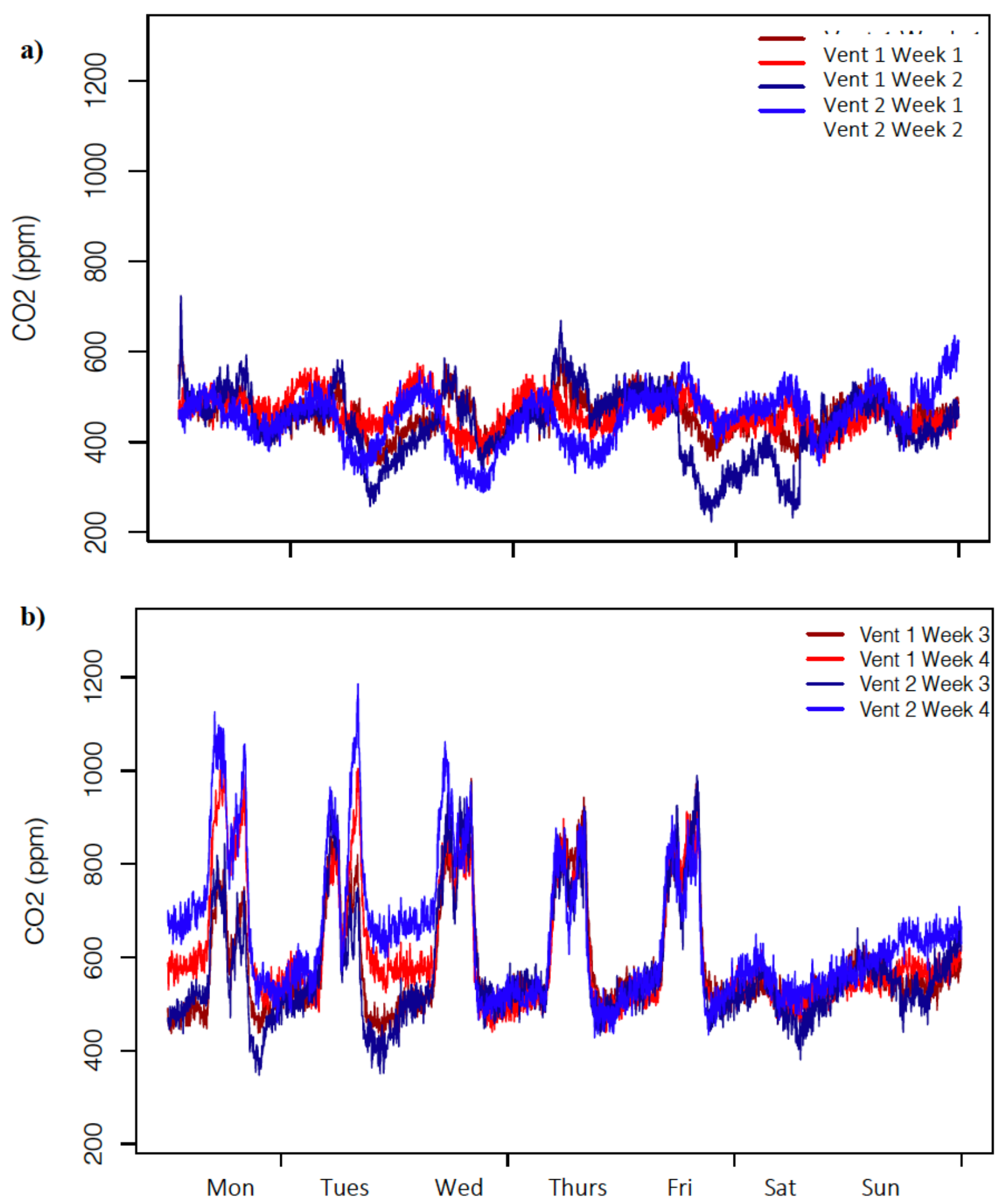

Figure 3

$\mathrm{CO} 2$ released from rooftop vents on a building while unoccupied and occupied. Sensors were attached to two vents on The BUA roof for four weeks. During the a) first two weeks, only baseline staff were present and the second two weeks a camp was being run. There were no $\mathrm{CO} 2$ peaks in the first two weeks and 
peaks up to $1300 \mathrm{ppm}$ during the second two weeks indicating the connection between Exhaust Vent CO2 and building occupancy.
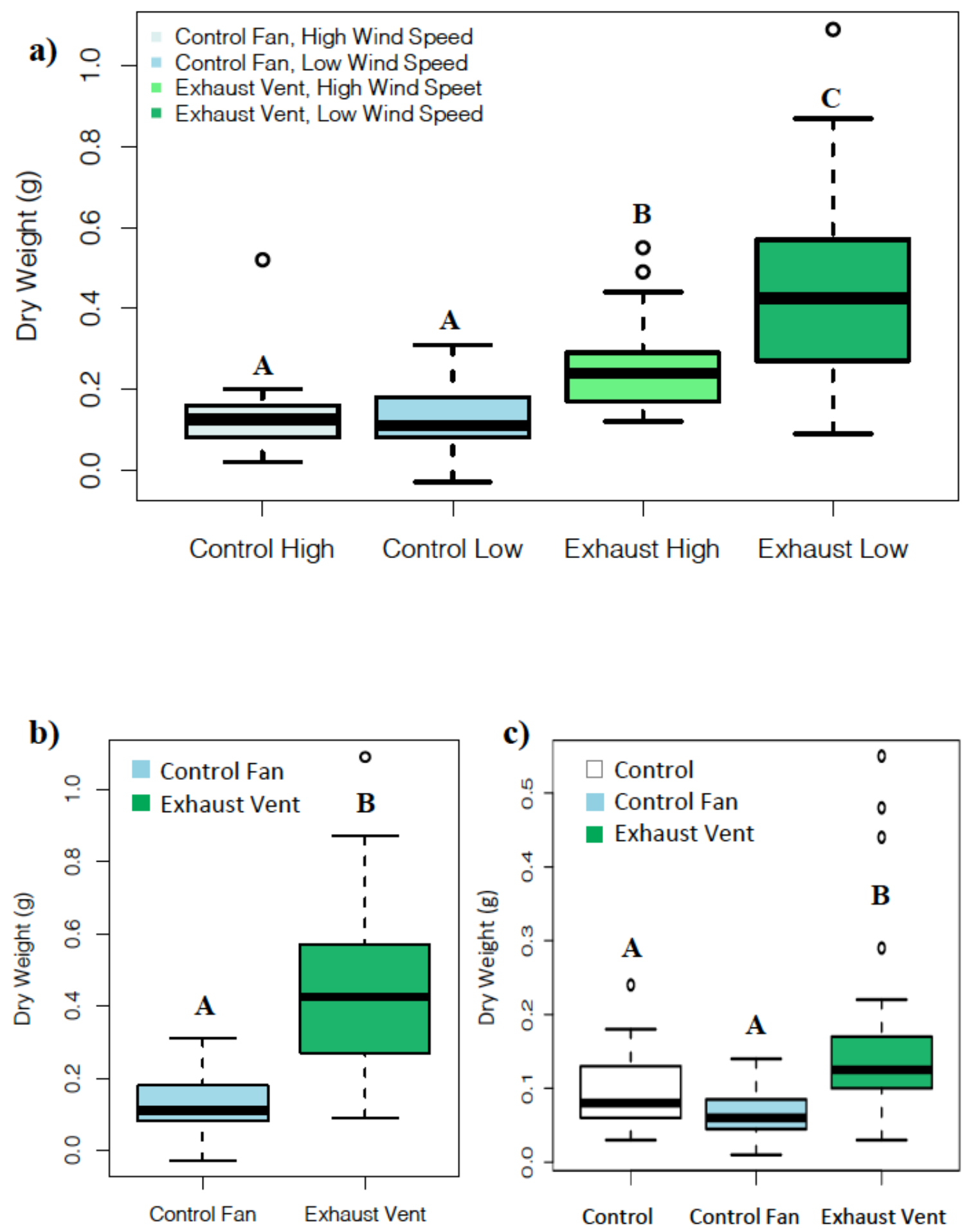

Figure 4

Average dry weight of spinach and corn plants in response to Exhaust Vent air. a) Spinach was grown in Fall 2018 next to two fans at a higher wind speed $(17 \mathrm{mph})$ and two at a lower speed $(10 \mathrm{mph})$ and one of each of these was a Control Fan and Exhaust Vent. Between the Exhaust Vents, the spinach plants 
exposed to high wind speeds were smaller $(p<.001)$. Even with this, the Exhaust Vent was able to recover growth compared to both the low $(p=.0058)$ and high-speed $(p=.0028)$ Control Fans. At only low wind speeds there was a significant increase in $b)$ dry biomass $(p<.001)$ with exposure to exhaust air. These data were from harvest 3. c) Corn was grown in Spring 2019 to look at the response of a crop that should not respond strongly to $\mathrm{CO} 2$. Another control was added to further assess the effect of wind speed. Corn grown next to the Exhaust Vent was larger than at both the Control Fan $(p<.001)$ and control garden $(p=$ 0.0045). Different capital letters indicate statistically significant differences among treatments.

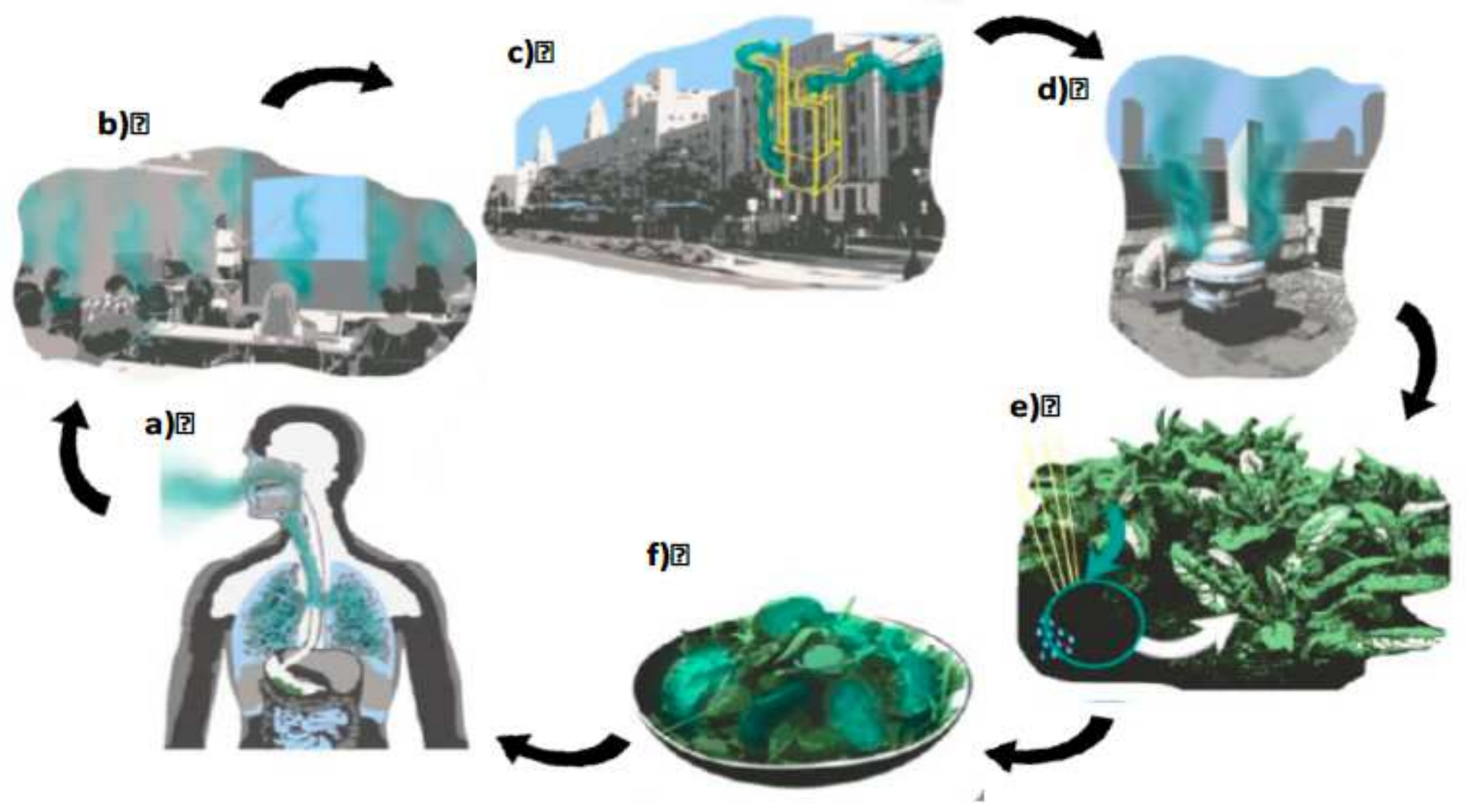

\section{Figure 5}

Conceptual diagram showing the carbon cycle within experimental rooftop gardens. CO2 travels a) from the human body b) out into the classroom within a building. This $\mathrm{CO} 2$ then is brought $c$ ) through the ventilation system to the rooftop and d) released through an exhaust vent. Our system will apply this $\mathrm{CO} 2$ to e) plants in a rooftop garden after which $\mathrm{f}$ ) humans can consume the crops and the carbon can return to the human body.

\section{Supplementary Files}

This is a list of supplementary files associated with this preprint. Click to download.

- BuckleySarabethSupplementaryInformation.pdf 